\title{
Influence of the Amazon River plume on distributions of free-living and symbiotic cyanobacteria in the western tropical north Atlantic Ocean
}

\author{
R. A. Foster ${ }^{1}$
}

Institute of Marine Science, University of California, Santa Cruz, California 95064

\author{
A. Subramaniam \\ Lamont Doherty Earth Observatory, Palisades, New York 10964
}

\section{Mahaffey}

Department of Oceanography, SOEST, University of Hawai'i, Honolulu, Hawai'i 93822

\author{
E. J. Carpenter \\ Romberg Tiburon Center, San Francisco State University, Tiburon, California 94920
}

\section{G. Capone}

Wrigley Institute of Marine Science and Department of Biological Sciences, University of Southern California, Los Angeles, California 90089

\section{J. P. Zehr}

Institute of Marine Science, University of California, Santa Cruz, California 95064

\begin{abstract}
The vertical and horizontal distributions of seven diazotrophic populations in the western tropical north Atlantic (WTNA) Ocean were examined using a nifH DNA quantitative polymerase chain reaction (QPCR) approach. The nifH phylotype abundances were highest near the surface and decreased with depth, with the exception of the cyanobacterial symbiont Calothrix, which was not detected at any station. Richelia associated with the diatoms Rhizosolenia clevei and Hemiaulus hauckii were distributed within the freshwater lens of the Amazon plume. Abundances of $H$. hauckii-Richelia nifH genes dominated all depths in 6 of 10 vertical profiles and 10 of 20 surface samples. In addition, estimates of Richelia associated with $H$. hauckii increased northwest (8$\left.12^{\circ} \mathrm{N}, 56-54^{\circ} \mathrm{W}\right)$ from the river mouth, where significantly $(p<0.001)$ higher abundances $\left(>10^{5}\right.$ copies $\left.\mathrm{L}^{-1}\right)$ were found in mesohaline waters (31-34.9). nifH copy abundance for surface populations of the H. hauckii-Richelia symbioses were positively correlated $\left(r^{2}=0.59\right)$ with salinity. Three unicellular cyanobacterial groups and Trichodesmium had similar horizontal distributions, where the highest nif $H$ copy estimates were at stations with salinity $\geq 35$ and northeast $\left(6-10^{\circ} \mathrm{N} 50^{\circ} \mathrm{W}\right)$ of the freshwater lens. The abundance of Trichodesmium spp. and unicellular Group B nifH gene copies co-varied $\left(r^{2}=0.60\right)$. The QPCR study showed the dominance of $H$. hauckii-Richelia symbioses in the Amazon plume waters, implying that these associations had an ecological advantage over the other diazotrophs. Outside of the plume nutrients were below detection, abundances of freeliving unicellular cyanobacterial phylotypes, including a novel group designated Group C, were abundant $\left(>10^{5}\right.$ copies $\mathrm{L}^{-1}$ ) and comparable to the abundances of Trichodesmium spp. Thus, there appeared to be a cascade of diazotrophic communities along gradients of salinity and nutrients in the WTNA.
\end{abstract}

Phytoplankton biomass and primary production is controlled by a variety of environmental factors, including nutrient availability, temperature, irradiance, and vertical stratification of the euphotic zone (mixed layer depth). Typically, nitrogen is considered the most limiting nutrient for phytoplankton growth (Ryther and Dunstan 1971;

\footnotetext{
${ }^{1}$ Corresponding author (rfoster@pmc.ucsc.edu). Current address: Lamont Doherty Earth Observatory, Palisades, New York 10964. Acknowledgments

We thank the captains and crews of the R/V Seward Johnson (2003) for their assistance in the field collections. We also thank B.E. McLaughlin for his support in data analyses and S.M. Short and M.J. Church for their advice and valuable insights during method development. R.A.F. also thanks T.R.C. for his support. and lastly the authors thank two anonymous reviewers for their comments and helpful suggestions.

The National Science Foundation (OCE-0196186, OCE-0196427 to EJC) and the Gordon and Betty Moore Foundation supported our research. C.M. would like to acknowledge the University of Southern California "Women in Science and Engineering" Fellowship for financial support during this research project. A.S. was funded by the NASA Ocean Biology and Biogeochemistry Program. This is LDEO contribution 6991.
} 
Hecky and Kilham 1988), however, others argue that phosphorus and iron (Fe) are equally important in regulating productivity and community composition (Falkowski 1997; Coale et al. 1998; Tyrrell 1999). Fe limitation is especially important for diazotrophs, since $\mathrm{Fe}$ is needed for the nitrogenase enzyme (Falkowski 1997; Berman-Frank et al. 2001; Kustka et al. 2002).

Fluvial inputs carry significant amounts of nutrients into oceanic waters affecting the nutrient regime and have a large impact on phytoplankton community structure. Satellite images of the western tropical north Atlantic (WTNA) show two large plumes, each more than $100 \mathrm{~km}$ wide, forming from April to November. The smaller plume originates around $5^{\circ} \mathrm{N}$ from the Orinoco River, and the larger outflow at the equator is derived from the Amazon River. The Amazon River represents the world's largest fluvial input, releasing on average $1.93 \times 10^{5} \mathrm{~m}^{3} \mathrm{~s}^{-1}$ of water (Perry et al. 1996) highly enriched with nutrients and suspended materials to the WTNA. The Orinoco and Amazon Rivers have similar silicate and salinity signatures, but differ in their outflow regime (Corredor and Morell 2001). These inputs bring silica, phosphorus, and $\mathrm{Fe}$ into the WTNA oceanic waters.

The Amazon River plume spreads northwest toward the Caribbean in the first half of the year. Then, in the latter part of the year, with a stronger western boundary current, the plume flows around the North Brazil Current retroflection $\left(-10^{\circ} \mathrm{N}\right)$ and flows eastward in the North Equatorial Countercurrent (Muller-Karger et al. 1988; 1995). The influence of the river plumes are farreaching; freshwater lenses with distinct phytoplankton populations and enhanced nutrients have been reported $>1,600 \mathrm{~km}$ away from the river mouths (Borstad 1982a; $1982 b$ ).

Smith and DeMaster (1996) reported, based on earlier observations in the Amazon River Basin, that low biomass occurred in two spatially distinct regions. They suggested that the community within the plume was limited by low light conditions due to high suspended solids and that production outside the freshwater lens was controlled by low nutrient concentrations. Surface flow is extremely rapid $\left(80 \mathrm{~cm}^{-1}\right)$, thus, much of the dissolved nutrients supplied by the Amazon escape the immediate vicinity of discharge (DeMaster et al. 1983). DeMaster et al. (1983) showed that maximum biogenic silica production was confined within a sharp salinity gradient off the Amazon delta where nutrients were high and suspended materials were low. Eddy upwelling (Woods 1988) or horizontal advection of plume waters are typically cited as the primary mechanisms for relieving nutrient stress and sustaining growth in the WTNA (Muller-Karger et al. 1988; Longhurst 1993; Muller-Karger et al. 1995). Most studies of diazotrophy in the WTNA have focused on Trichodesmium (Carpenter et al. 2004; Capone et al. 2005), with the exception of Carpenter et al. (1999).

Phytoplankton composition within the Amazon River plume was studied by Borstad $(1982 a ; 1982 b)$ and more recently by Carpenter et al. (1999). Borstad (1982b) found the colonial diazotroph Trichodesmium spp. present at high abundances near Barbados when the plume was present.
Later, Smith and Russell (1995) found that the vertical stability of the water column controlled the distribution of phytoplankton chlorophyll $a(\mathrm{Chl} a)$ within the plume. Carpenter et al. (1999) reported large and expansive diatom blooms of Hemiaulus hauckii with its associated cyanobiont, Richelia intracellularis, in the regions of the WTNA that were influenced by the Orinoco and Amazon River plumes. The measured rate of nitrogen $\left(\mathrm{N}_{2}\right)$ fixation by the diatom-diazotrophic association (DDA) bloom was greater than the estimated nitrate flux from below the euphotic zone. Therefore, Carpenter et al. (1999) proposed that the $\mathrm{N}_{2}$ fixation by DDAs can, perhaps, be an important source of new nitrogen in oligotrophic tropical waters. Few current ecosystem models consider inputs from biological $\mathrm{N}_{2}$ fixation as significant sources of new nitrogen to the euphotic zone (Capone et al. 2005).

Studies of natural phytoplankton communities are hindered by the difficulties in identifying, isolating, and collecting individual populations. Typically, field populations of plankton are counted by microscopy, which relies heavily on the observer's ability to distinguish taxa and assumes species identifications by the various observers are consistent. Recently, several real-time (quantitative) polymerase chain reaction (PCR) assays have been developed and successfully used in a variety of applications, including estimating the abundance of specific planktonic microbial populations (Suzuki et al. 2000; Short et al. 2004; Church et al. 2005a). In real-time PCR technology, a specific PCR product is quantified by continuously monitoring product accumulation during the reaction using fluorescent probes. Quantitative PCR (QPCR) methods can be highly specific and when the target PCR product is known, or assumed to occur as a single gene copy in an organism, QPCR can be used as an alternative method for estimating species abundances.

All diazotrophic taxa use the nitrogenase enzyme for $\mathrm{N}_{2}$ fixation. The enzyme is composed of two proteins encoded by the nifHDK genes. The nifH gene encodes for the iron protein of the nitrogenase enzyme and is highly conserved (Falkowski 1997; Zehr et al. 2000). Among the open ocean cyanobacteria, nifH sequences have been identified for Trichodesmium. Three heterocystous cyanobionts (het-1, het-2, het-3) (Foster and Zehr 2006) and one of two environmental nifH sequences (unicellular Group B) found in the subtropical Pacific Ocean can be identified to a cultured isolate (Crocosphaera watsonii WH 8501) (Waterbury and Rippka 1989). The other environmental nifH sequences (Group A) ( Zehr et al. 2001b; Church et al. $2005 a ; 2005 b$ ) have yet to be linked to a cultivated isolate or a microscopically identified organism.

In this study, we designed QPCR assays to target the nifH gene of three (Chaetoceros, Hemiaulus, Rhizosolenia) different diatom-cyanobiont symbioses and applied these to samples collected during the spring (April-May $2003)$ in the WTNA. In addition, we designed another specific primer and probe combination for a novel nifH phylotype, which was amplified from one of the collected samples. The nifH gene abundance for the free-living nonheterocystous cyanobacterium Trichodesmium and two unicellular cyanobacteria phylotypes (Groups A and 
B) were also assayed by QPCR. Samples were collected during the high flow season of the Amazon River plume. The goal of this study was to determine the vertical abundances of symbiotic and free-living diazotrophs and whether the Amazon River plume influences the horizontal abundance distribution of individual diazotrophic populations.

\section{Materials and methods}

Sample collections - Stations where samples were collected in the WTNA $\left(7-12^{\circ} \mathrm{N}\right.$ and $\left.57-47^{\circ} \mathrm{E}\right)$ are shown in Fig. 1. Stations (Sta.) 3 to 15 were sampled daily from 20 30 April 2003, and Sta. 17 through 69 were sampled from 1-20 May 2003 (Fig. 1). Seawater was sampled from 4-6 depths from 20 stations using a conductivity-temperaturedepth (CTD) rosette. Ten liters of water were drained from the Niskin bottles into 10-liter carboys. Using a peristaltic pump, 2-10-liter water samples were filtered through 0.45 $\mu \mathrm{m}$ pore-size Supor filters (Pall Corporation) held within 25-mm-diameter Swinnex filter holders (Millipore). The filters were folded in half, frozen in liquid nitrogen, and stored at $-80^{\circ} \mathrm{C}$ until processed in the laboratory.

Microscopy observations - Samples for epifluorescence microscopy were taken from parallel bottles sampled at the same discrete depths as the water samples collected for the QPCR study. The entire contents of the Niskin bottle were gravity filtered onto a 47-mm-diameter Poretics (Millipore) membrane filter with a pore size of $5 \mu \mathrm{m}$. Gravity-filtration time varied from $30 \mathrm{~min}$ to $2 \mathrm{~h}$. If the filter clogged by $2 \mathrm{~h}$,

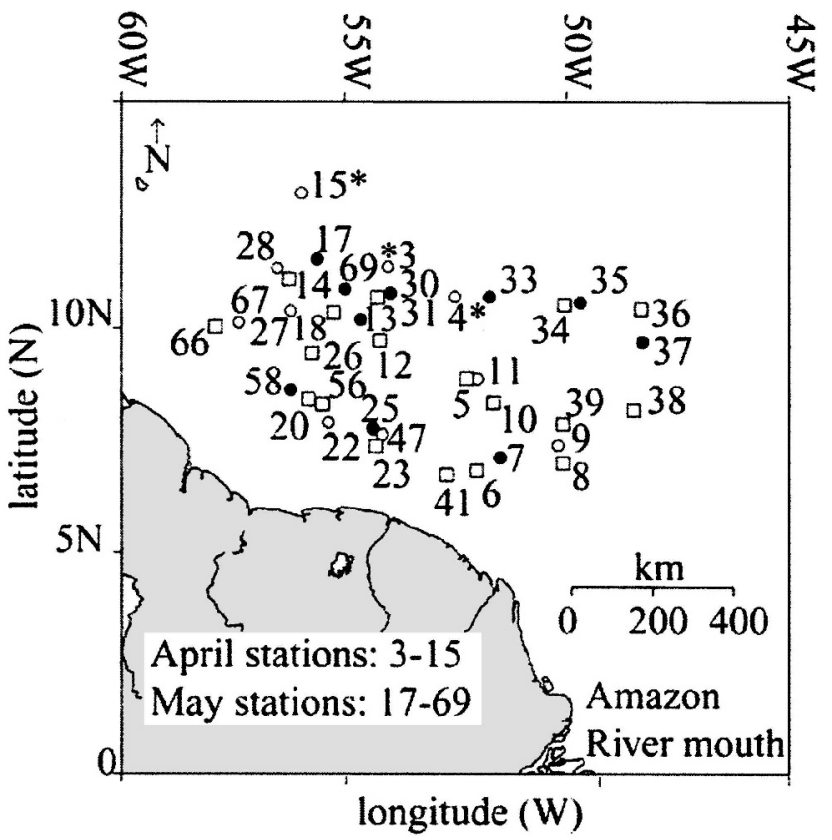

Fig. 1. Map of WTNA area with station locations. Stations sampled for nutrients are designated with a rectangle, open circles represent the QPCR sampling stations, and filled circles were stations processed at 4-6 depths in the QPCR study. Asterisks designate stations where both nutrients and samples for the QPCR study were taken. the remaining volume in the Niskin was measured with a graduated cylinder, and the filtered volume was calculated. Phycoerythrin and Chl $a$ was used to visualize cyanobacteria by epifluorescence microscopy using green $(510-560 \mathrm{~nm})$ and blue $(450-490 \mathrm{~nm})$ excitation wavelengths, respectively. Cyanobacteria were identified by phycoerythrin (red) and chlorophyll (yellow-orange) fluorescence.

Nutrient analyses - Seawater for nutrient analyses was collected from 21 stations using a CTD at the same or similar depths as those collected for the QPCR study. Because of time and water budget constraints, 18 of the depth profiles were collected at daytime stations that were within about 30 nautical miles of the night stations sampled for the QPCR study (Fig. 1). Water samples for inorganic nutrient analysis were collected in $125-\mathrm{mL}$ high-density polyethylene acid-rinsed bottles and frozen upright immediately after collection. Nitrate, phosphate, and silicate concentrations were determined by standard colorimetric techniques using a segmented-flow Bran and Luebbe autoanalyzer at the University of Hawai'i. Detection limits for nitrate, phosphate, and silicate were $0.1,0.05$, and $0.5 \mu \mathrm{mol}$ $\mathrm{L}^{-1}$, respectively.

Remote sensing - Ocean color remote sensing data was acquired with the sea-viewing wide field-of-view sensor (SeaWiFS) on board the Seastar satellite. Monthly composites for April and May 2003 were compiled, and using the operational K490 algorithms, diffuse attenuation at 490-nm values (K490) were determined (O'Reilly 2000). Based on the strong relationships between colored dissolved organic matter (CDOM) and K490, and between CDOM and salinity, the K490 values were used to predict salinity (Del Vecchio and Subramaniam 2004). Cruise tracks were added to the monthly composites using SeaDAS (Fu et al. 1998).

DNA extraction - Nucleic acids were extracted using the DNeasy plant mini kit (Qiagen) with minor modifications of the manufacturer's protocol. Tubes containing 330- $\mu \mathrm{L}$ lysis buffer, $4-\mu \mathrm{L}$ RNAse solution, filter samples, and $\sim 30$ $\mu \mathrm{L}$ of a $0.1-\mathrm{mm}$ and $0.5-\mathrm{mm}$ glass bead mixture $(50: 50)$ (Biospec) were initially subjected to a 2-min bead beat step on level 6 of the fast prep machine (Bio 101). The tubes were then centrifuged briefly at $8,000 \times g$, the supernatant was applied to Qiagen shredder columns, and the DNA was purified following the manufacturer's recommendations and eluted in 35- $\mu \mathrm{L}$ of elution buffer (EB) (Qiagen). DNA concentrations were quantified with PicoGreen (Molecular Probes) using a spectrofluorometer (Varian).

nifH PCR, cloning, and sequencing - Twenty-one samples were processed using a nested PCR method to amplify a 359 base pair (bp) fragment of the nifH gene with two sets of degenerate primers (Zehr and Turner 2001a). The samples included 3 depth profiles (4-6 depths) from Sta. 13, 15, and 31, and 15-m and 30-m samples from Sta. 34 and 27, respectively (Fig. 1). The PCR amplifications were performed with a Gene Amp 1800 thermal cycler (Applied 
Biosystems). Reaction mixtures included: $2 \mu \mathrm{L}$ of template DNA $(2.0-10 \mathrm{ng}) ; 32.5 \mu \mathrm{L}$ nuclease free water; $8.0 \mu \mathrm{L}$ of $25 \mathrm{mmol} \mathrm{L}-1$ magnesium chloride; $5.0 \mu \mathrm{L}$ of $10 \mathrm{X}$ Dynazyme reaction buffer (Qiagen); $2.0 \mu \mathrm{L}$ of $10 \mathrm{mmol} \mathrm{L}^{-1}$ each deoxynucleotide triphosphates (dATP, dCTP, dGTP, dTTP); $0.5 \mu \mathrm{L}$ each of $100 \mu \mathrm{mol} \mathrm{L}^{-1}$ nifH3 and nifH4 primers each (Zehr and Turner 2001a); and $0.5 \mu \mathrm{L}$ $(0.5 \mathrm{U})$ of $T a q$ polymerase (Qiagen) (total final reaction volume of $50 \mu \mathrm{L}$ ). Reaction conditions consisted of an initial denaturing step at $94^{\circ} \mathrm{C}$ for $4 \mathrm{~min}$, then 25 cycles of $30 \mathrm{~s}$ each at $94^{\circ} \mathrm{C}, 57^{\circ} \mathrm{C}$, and $72^{\circ} \mathrm{C}$, followed by a final extension at $72^{\circ} \mathrm{C}$ for $7 \mathrm{~min}$. In the second round of PCR the same reaction mixture and conditions were used, however, nifH1 and nifH2 primers (Zehr and Turner $2001 a$ ) were used and $1 \mu \mathrm{L}$ of round 1 product was added. A nuclease free water addition was used for negative controls in the PCRs; no amplification of negative controls was detected.

The $50-\mu \mathrm{L}$ PCR reactions were analyzed on a $1.2 \%$ agarose gel. For samples that produced a 359 bp product, the band was excised and purified with the QIAquick gel purification kit (Qiagen) according to the manufacturer's protocol. Products were eluted in 35- $\mu \mathrm{L}$ EB buffer (Qiagen), and $2 \mu \mathrm{L}$ of the purified product was immediately cloned with the PGEM-Easy Vector system (Promega) following the manufacturer's protocol. Eight to 28 white colonies per ligation were restreaked onto new plates and inoculated in $1-\mathrm{mL}$ aliquot of $2 \times$ Luria-Bertani media amended with a final concentration of $100 \mu \mathrm{g} \mathrm{mL}-1$ carbinicillin in sterile 96 deep-well blocks. Cells were incubated overnight at $37^{\circ} \mathrm{C}$ and agitated. Plasmids were purified using the Montáge plasmid miniprep p $_{96}$ kit (Millipore) following the manufacturer's partial lysate protocol.

Three microliters of purified plasmid miniprep were sequenced using SP6 or T7 primers $\left(5 \mathrm{pmol} \mu \mathrm{L}^{-1}\right)$ with the ABI Prism BigDye Terminator (BDT) reaction mix $(1.0 \mu \mathrm{L}$ $\mathrm{BDT}$ and $0.5 \mu \mathrm{L}$ ABI $5 \times$ sequencing buffer) (PerkinElmer) according to the manufacturer's protocols. For each sequencing reaction, the product was cleaned using the Montáge SEQ $_{96}$ sequencing reaction kit (Millipore), and the DNA was sequenced with an ABI 3100 gene analyzer (Applied Biosystems).

Sequence analysis-Vector and primer sequences were removed using Seqlab of the GCG Wisconsin package version 10.3. For each library, sequences were considered different if they differed by $>1 \mathrm{bp}$. Twenty-four of the nifH sequences determined in the study were deposited in GenBank under accession numbers: DQ404410DQ404433 and DQ273169 (a representative of unicellular cyanobacterium Group C, see Oligonucleotide design below).

Oligonucleotide design - nifH sequences obtained from Richelia associated with natural populations of $H$. hauckii and Rhizosolenia clevei and a Calothrix isolate from a Chaetoceros diatom were used to design host-specific TaqMan (Applied Biosystems) PCR primers and probes (Table 1) (Foster and Zehr 2006). In addition, the nifH sequence of clone AO_5202A67 (accession no. DQ273169) from Sta. 13 was also used to design a TaqMan oligonucleotide primer and probe set that targets Group C unicellular cyanobacterial nifH (Table 1). Primer Express (Applied Biosystems) software was used for primer design, and the specificity of the primers and probes was tested with an ARB (Ludwig et al. 2004) database containing all nifH sequences available in GenBank as of May 2005 and also in a series of experiments (see below). We used the het1 TaqMan primer and probe previously described by Church et al. (2005a) because we obtained nifH sequences identical to those of Church et al. (2005a) from Richelia associated with $R$. clevei (Table 1) (Foster and Zehr 2006). In addition, we used primers and probes that target diazotrophic unicellular cyanobacteria Groups A and B and the filamentous nonheterocystous cyanobacterium, Trichodesmium spp. (Church et al. 2005a) (Table 1).

Table 1. TaqMAN oligonucleotides used for the QPCR analyses. The numbers in parentheses designate the target positions relative to the aligned nucleotide sequence of Azotobacter vinelandii (accession number AY351672).

\begin{tabular}{|c|c|c|c|}
\hline Target & Forward primer $5^{\prime}------3^{\prime}$ & Probe & Reverse primer $5^{\prime}----3^{\prime}$ \\
\hline $\begin{array}{l}\text { R. } \text { clevei- } \\
\text { Richelia*† }\end{array}$ & $\begin{array}{l}\text { CGGTTTCCGTGGTGTACGTT } \\
(105-124)\end{array}$ & $\begin{array}{l}\text { TCCGGTGGTCCTGAGCCTGGTGT } \\
(133-155)\end{array}$ & $\begin{array}{l}\text { AATACCACGACCCGCACAAC } \\
(158-177)\end{array}$ \\
\hline $\begin{array}{l}\text { H. haukii- } \\
\text { Richelia } \dagger\end{array}$ & $\begin{array}{l}\text { TGGTTACCGTGATGTACGTT } \\
(106-124)\end{array}$ & $\begin{array}{l}\text { TCTGGTGGTCCTGAGCCTGGTGT } \\
(133-155)\end{array}$ & $\begin{array}{l}\text { AATGCCGCGACCAGCACAAC } \\
(158-177)\end{array}$ \\
\hline $\begin{array}{l}\text { Chaetoceros- } \\
\text { Calothrix } \dagger\end{array}$ & $\begin{array}{l}\text { CGGTTTCCGTGGCGTACGTT } \\
(106-124)\end{array}$ & $\begin{array}{l}\text { TCTGGTGGTCCAGAACCTGGTGT } \\
(133-155)\end{array}$ & $\begin{array}{l}\text { AATACCACGACCAGCACAAC } \\
(133-155)\end{array}$ \\
\hline Trichodesmium & $\begin{array}{l}\text { GACGAAGTATTGAAGCCAGG } \\
\text { TTTC }(217-241)\end{array}$ & $\begin{array}{l}\text { CATTAAGTGTGTTGAATCTGGTG } \\
\text { GTCCTGAGC (246-278) }\end{array}$ & $\begin{array}{l}\text { CGGCCAGCGCAACCTA } \\
(284-300)\end{array}$ \\
\hline Group A & $\begin{array}{l}\text { AGCTATAACAACGTTTTATGC } \\
\text { GTTGA }(106-131)\end{array}$ & $\begin{array}{l}\text { TCTGGTGGTCCTGAGCCTGGA } \\
(133-153)\end{array}$ & $\begin{array}{l}\text { ACCACGACCAGCACATCCA } \\
(156-174)\end{array}$ \\
\hline Group B & $\begin{array}{l}\text { TGGTCCTGAGCCTGGAGTTG } \\
(138-157)\end{array}$ & $\begin{array}{l}\text { TGTGCTGGTCGTGGTAT } \\
(160-176)\end{array}$ & $\begin{array}{l}\text { TCTTCTAGGAAGTTGATGG } \\
\text { AGGTGT (178-203) }\end{array}$ \\
\hline Group C & $\begin{array}{l}\text { ATACCAAGGAATCAAGTGTG } \\
\text { TTGAGT (106-131) }\end{array}$ & $\begin{array}{l}\text { CGGTGGTCCCGAGCCTGGAG } \\
(133-153)\end{array}$ & $\begin{array}{l}\text { ACCACGACCAGCACATCCA } \\
(156-174)\end{array}$ \\
\hline
\end{tabular}

\footnotetext{
* Church et al. (2005a) designed primer set to target het-1 group.

$\dagger$ Designed based on sequence data reported in Foster and Zehr (2006).

$\$$ Church et al. (2005a) designed primer set to target Trichodesmium and Katagnyeme spp. phylotypes.
} 
The specificity of the oligonucleotides was tested by the addition of nontarget controls (75-80\% similar); linearized plasmids containing Trichodesmium spp. nifH were used in assays with Richelia/Calothrix and unicellular cyanobacteria Groups A, B, and C primer and probe sets. The experiments were run in triplicate, and no amplification was ever detected. In addition, we tested the cross reactivity of the three heterocystous cyanobionts and three unicellular cyanobacterial primer and probe sets. The standard curve for each target was run in TaqMan reactions with the other two primers and probe sets to determine the extent of cross reactivity of primers and probes. For example, the $H$. hauckii-Richelia TaqMan primers and probes were run in reactions with $R$. clevei-Richelia and Chaetoceros-Calothrix template DNA. Similarly, for example, the Group C TaqMan primers and probes were run in reactions with Group A and Group B template DNA.

TaqMan assays-For all TaqMan PCR, the $25-\mu \mathrm{L}$ reactions contained $12.5 \mu \mathrm{L}$ of $2 \times$ TaqMan buffer (Applied Biosystems), $8.0 \mu \mathrm{L}$ of $5 \mathrm{kD}$-filtered nuclease-free water (Ambion), $0.5 \mu \mathrm{mol} \mathrm{L} \mathrm{L}^{-1}$ each of the forward and reverse primers, $0.25-\mu \mathrm{mol} \mathrm{L}^{-1}$ fluorogenic probe, and $2 \mu \mathrm{L}$ of template DNA. Although the final concentration of DNA varied from $2 \mathrm{ng}$ to $10 \mathrm{ng}$ per reaction, the volume $(2 \mu \mathrm{L})$ added to each reaction was consistent. For the nontemplate controls, $2 \mu \mathrm{L}$ of $5-\mathrm{kD}$-filtered nuclease-free water (Ambion) was added to each reaction, and these were run in quadruplicate. For every sample, $5^{\prime}$ nuclease reactions were replicated in quadruplicate, with the fourth replicate used to estimate the reaction efficiency (see PCR efficiency below). The PCR amplifications were conducted in a GeneAmp 9700 sequence detection system (Applied Biosystems) with the following parameters: $50^{\circ} \mathrm{C}$ for $2 \mathrm{~min}, 95^{\circ} \mathrm{C}$ for $10 \mathrm{~min}$, and 45 cycles of $95^{\circ} \mathrm{C}$ for $15 \mathrm{~s}$ followed by $60^{\circ} \mathrm{C}$ for $1 \mathrm{~min}$. Gene copy numbers were calculated from the mean cycle threshold $\left(\mathrm{C}_{\mathrm{t}}\right)$ value of three replicates and the standard curve for the appropriate primer and probe set (see Standard curves below). In some samples only two of the three replicates produced an amplification signal; these were noted as detectable, but not quantifiable.

In heterocystous cyanobacteria, more than one nifH gene copy per genome occurs. In addition, there is a nifH gene copy in the heterocyst and vegetative cells of a trichome. Typically, the multiple copies per genome are divergent enough (i.e., Anabeana variabilis ATCC 51142 divergence $>20 \%$ ) to not affect QPCR estimates. However, the number of copies needs to be normalized to trichome length to account for the copies in the vegetative cells. In our microscopy observations we noted that, on average, the Richelia trichome associated with $H$. hauckii and $R$. clevei were composed of four and five cells, respectively (includes one terminal heterocyst). Thus, for normalizing the gene copies of Richelia associated with the latter hosts, the mean estimate was divided by three and four, respectively. Genome sequencing projects of Trichodesmium IMS101 and Crocosphaera watsonii 8501 show one nifH gene copy per cell, so no normalization was required for our Trichodesmium spp. estimates and for Group B because the nifH of Group B is $97 \%$ similar (nucleotide) to $C$. watsonii 8501. We assumed Groups $\mathrm{A}$ and $\mathrm{C}$ had one nifH gene copy per cell because these are phylogenetically similar (80-90\%) to Group B.

Standard curves-For each primer and probe set, duplicate standard curves were made from 10 -fold dilution series ranging from $10^{8}$ to 1 gene copies per reaction. The standard curves were made from linearized plasmids of the target nifH. Regression analyses of the results (number of cycles $=\mathrm{C}_{\mathrm{t}}$ ) of the standard curves were analyzed in Excel.

PCR efficiency-The PCR efficiency for each sample was determined as previously described by Short et al. (2004), where the following formula was used: $X_{n}=X_{o} \times$ $\left(1+E_{x}\right)^{n}$, where $X_{o}$ is the initial number of target molecules, and $n$ is the number of cycles $\left(C_{t}\right)$. First, the sample amplification efficiency, $\mathrm{E}_{\mathrm{x}}$, is assumed to be one, and the $\mathrm{C}_{\mathrm{t}}$ value for the appropriate linearized plasmid alone was used to calculate the number of target molecules, $X_{n}$. $E_{x}$ is determined by using the calculated $X_{n}$ with the $C_{t}$ value from the fourth replicate of each sample, which contained $2 \mu \mathrm{L}$ of the plasmid plus $2 \mu \mathrm{L}$ of sample DNA. The $E_{x}$ value was converted to a percentage, and samples that amplified with $<95 \%$ efficiency were considered to be inhibited.

Statistical analyses - Results from the QPCR study (nifH gene copies $\mathrm{L}^{-1}$ ) were pooled, and values that were below detection or had a detectable signal that was not quantifiable were removed. Normality tests (Kolmogorov-Smirnov), correlations, linear regressions, one-way analysis of variance (ANOVA), and one-way analysis of variance on ranks (Kruskal-Wallis) were run in Sigma Stat 3.0. The Holm-Sidak method was used for all multiple pairwise comparisons.

\section{Results}

Surface lens as described by remote sensing-Monthly SeaWiFs composites of K490 were used to map the plume and thus study the plume dynamics in April and May 2003 (Fig. 2A,B). In April, the plume flowed northward along the Brazilian coastline and began to spread northwest (NW) to $14^{\circ} \mathrm{N}, 60^{\circ} \mathrm{W}$ approximately $1,900 \mathrm{~km}$ from the river mouth (Fig. 2A). Then in May, the plume continued to spread NW to latitude $15^{\circ} \mathrm{N}$. A narrow meander of lower-salinity water appeared to the east along the $10^{\circ} \mathrm{N}$ latitude toward the $50^{\circ} \mathrm{W}$ longitude (Fig. 2B). There were a few station locations $(4,9,33)$ in the northeast (NE) region of the transect that were not influenced by the plume in April and had lower surface salinities $(<30)$ in the May composite (Fig. 2A,B). In May, there were also more areas in the NW region that had lower salinities $(<30)$ than in April (Fig. 2A,B).

Hydrographic conditions - Surface water temperatures ranged from $26.1^{\circ} \mathrm{C}$ to $28.2^{\circ} \mathrm{C}$, with an average of $27.5^{\circ} \mathrm{C} \pm$ 0.4 in the upper $10 \mathrm{~m}$. Surface salinity was variable, ranging 

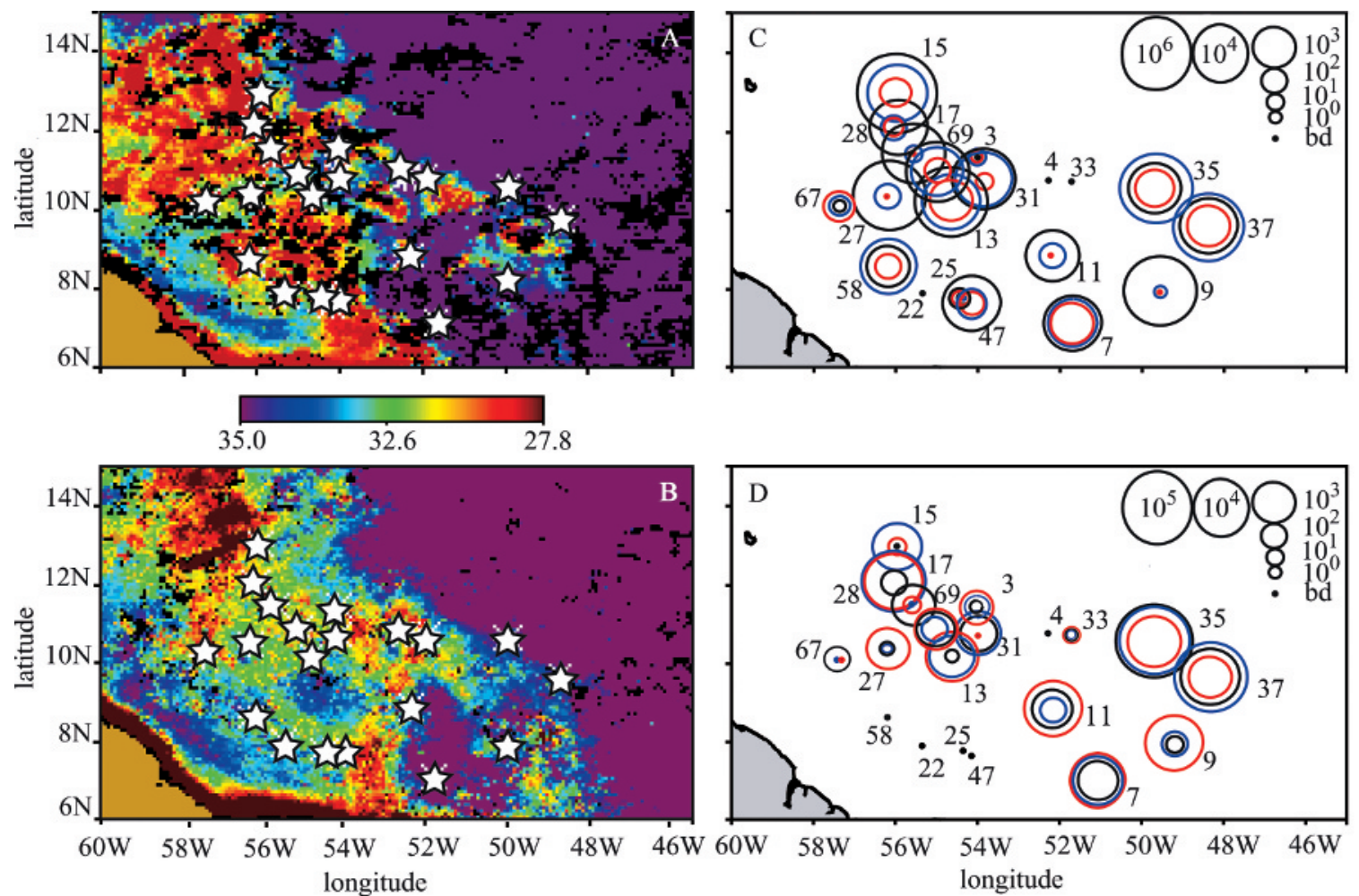

Fig. 2. Sea surface salinity for (A) April and (B) May calculated from monthly composites of SeaWiFS-derived diffuse attenuation coefficients (k490). Color scale represents the estimated salinity. The distribution of log nifH gene copies $\mathrm{L}^{-1}$ for $(\mathrm{C})$ larger diazotrophs: Hemiaulus-Richelia (black), Rhizosolenia-Richelia (red), and Trichodesmium spp. (blue) and (D) unicellular groups: A (black), B (blue), and C (red). Note that scales are not the same in panels C and D. The stations sampled for QPCR study are labeled on panels C and D, and it should be noted that Sta. 3-15 were sampled in April 2003 and 17-69 were sampled in May 2003.

24.3 to 36.3. Three categories were devised based on surface salinity: low (24-31), meso (31.1-34.9), and high ( $\geq 35)$.

Seven stations (Sta. 6, 23, 25, 41, 47, 56, and 69) fell within the freshwater lens of the Amazon River plume and had low surface salinity (24.3-31) (Table 2). Nutrients were measured at four (Sta. 6, 23, 41, and 56) of the six stations. Surface concentrations of silicate $\left(3.0-25.4 \mu \mathrm{mol} \mathrm{L}^{-1}\right)$ and phosphate $\left(0.13-0.16 \mu \mathrm{mol} \mathrm{L}^{-1}\right)$ were elevated (Table 2). Nitrate concentrations were relatively high at Sta. 41 and $56\left(0.5 \mu \mathrm{mol} \mathrm{L}^{-1}\right.$ and $0.1 \mu \mathrm{mol} \mathrm{L}^{-1}$, respectively $)$, but lower at Sta. 6 and $23\left(0.05 \mu \mathrm{mol} \mathrm{L}^{-1}\right)$ (Table 2). The freshwater lens was 14-m and 12-m thick at Sta. 25 and 47, respectively (Fig. 3A; Table 3). The vertical gradient was most abrupt at Sta. 69, where salinity changed by 5 within $1 \mathrm{~m}$ (Fig. 3C; Table 3). Concentrations of nitrate and phosphate were below detection at Sta. 69 (silicate was not measured).

Twenty stations (Sta. 7, 10-15, 17, 18, 20, 22, 26-28, 30, $31,58,66$, and 67) had intermediate or mesohaline surface salinities (31.1-34.9). Nutrient concentrations were

Table 2. Summary of surface nutrient concentration ranges for nitrate, phosphate, and silicate as a function of the surface salinity categories (low, meso, and high). Locations of stations where nutrients were measured are as shown in Fig. 1.

\begin{tabular}{|c|c|c|c|c|}
\hline Salinity & Stations & Nitrate $(\mu \mathrm{mol} \mathrm{L}-1)$ & Phosphate $(\mu \mathrm{mol} \mathrm{L}-1)$ & Silicate $(\mu \mathrm{mol} \mathrm{L}-1)$ \\
\hline \multirow[t]{3}{*}{ Low (24.3-31) } & 69 & $<0.01$ & $<0.02$ & na \\
\hline & 6,23 & 0.05 & 0.13 & $5.8,10.5$ \\
\hline & 41,56 & $0.5,0.1$ & $0.16,0.13$ & $25.4,3.0$ \\
\hline \multirow[t]{3}{*}{ Meso (31.1-34.9) } & $10,12,14,18, \dagger 26 \dagger$ & $<0.01$ & $<0.02$ & bd \\
\hline & 15,66 & $0.03,0.06$ & $\mathrm{bd}, 0.12$ & bd, 2.9 \\
\hline & $20,30 \%$ & $0.12,0.13$ & 0.13 & $0.95,2.4$ \\
\hline \multirow[t]{4}{*}{ High $(>35)$} & 4 & na & $\mathrm{bd}$ & 1.1 \\
\hline & $5,34, \dagger 38, \dagger 39$ & bd & $\mathrm{bd}$ & $\mathrm{bd}$ \\
\hline & 36 & $<0.01$ & $<0.02$ & bd \\
\hline & 8 & 0.06 & 0.15 & 0.06 \\
\hline
\end{tabular}

na, not analyzed; bd, below detection.

Not analyzed for silicate.

Not analyzed for phosphate. 

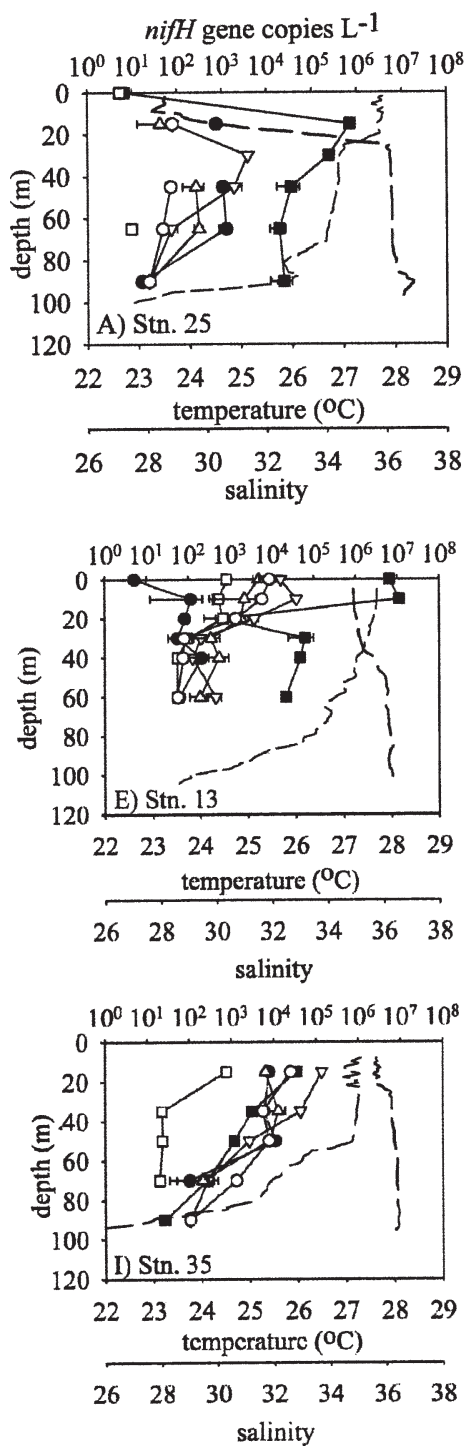

nifH gene copies $\mathrm{L}^{-1}$

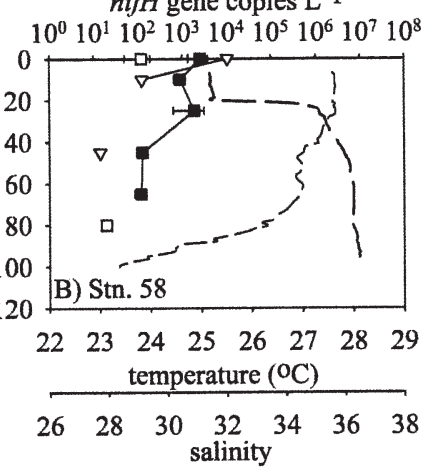

$10^{0} 10^{1} 10^{2} 10^{3} 10^{4} 10^{5} 10^{6} 10^{7} 10^{8}$

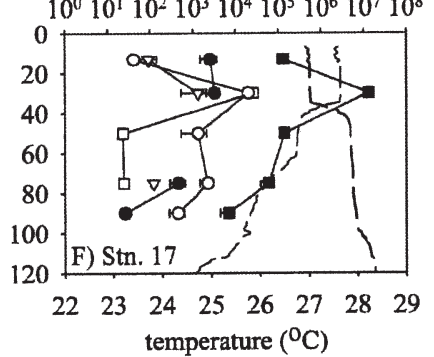

$$
\begin{array}{lllllll}
26 & 28 & 30 & 32 & 34 & 36 & 38
\end{array}
$$
salinity
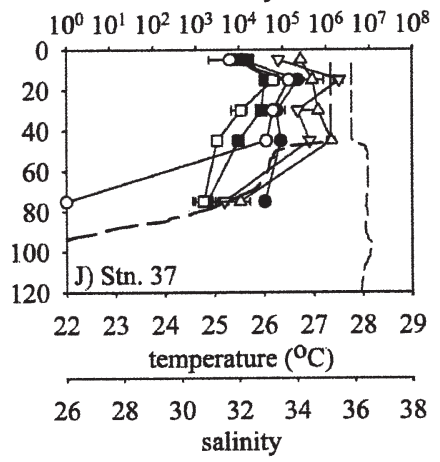

nifH gene copies $\mathrm{L}^{-1}$

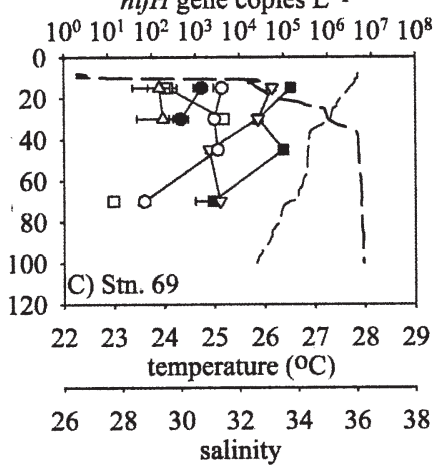

$10^{0} 10^{1} 10^{2} 10^{3} 10^{4} 10^{5} 10^{6} 10^{7} 10^{8}$

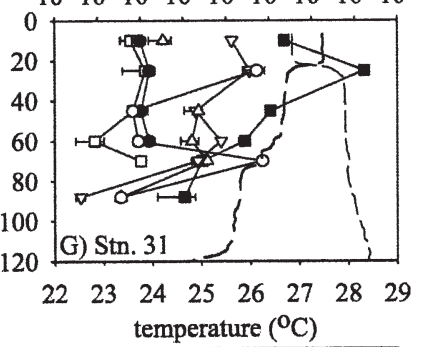

$\begin{array}{lllllll}26 & 28 & 30 & 32 & 34 & 36 & 38\end{array}$ salinity

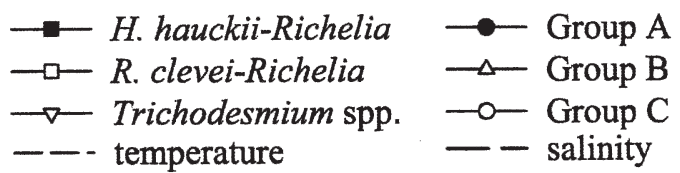

nifH gene copies $\mathrm{L}^{-1}$

$10^{0} 10^{1} 10^{2} 10^{3} 10^{4} 10^{5} 10^{6} 10^{7} 10^{8}$

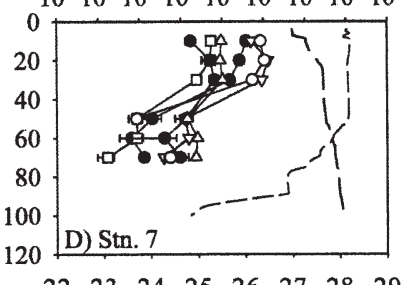

$\begin{array}{llllllll}22 & 23 & 24 & 25 & 26 & 27 & 28 & 29\end{array}$ temperature $\left({ }^{\circ} \mathrm{C}\right)$

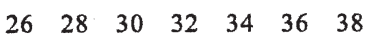
salinity

$10^{0} 10^{1} 10^{2} 10^{3} 10^{4} 10^{5} 10^{6} 10^{7} 10^{8}$

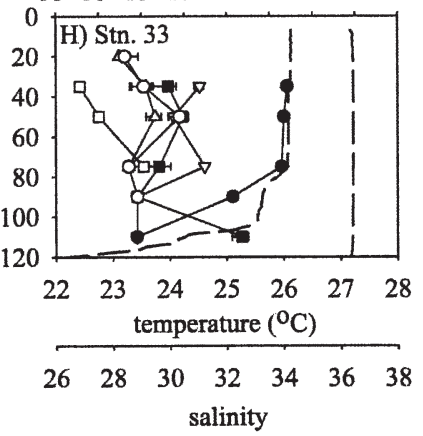

Fig. 3. Depth profiles for mean nifH gene copies $\mathrm{L}^{-1}$ (log value) for the target diazotrophs at 10 select stations. Error bars represent standard deviations of triplicate reactions. Gaps between depths of a particular target represent where phylotype was below detection or detected and not quantifiable. Input values for figures are provided in Table 3; A-J are ordered with increasing surface salinities (low, meso, high).

determined on samples collected throughout the water column from nine (Sta. 10, 12, 14-15, 18, 20, 26, 30, 66) of the 20 stations with mesohaline salinities. Three stations (Sta. 20, 30, and 66) had elevated silicate (0.5$\left.2.9 \mu \mathrm{mol} \mathrm{L}^{-1}\right)$ concentrations and Sta. 20 and 66 had high phosphate $\left(0.12-0.13 \mu \mathrm{mol} \mathrm{L}^{-1}\right)$ concentrations (Table 2). Nitrate concentrations were $0.06 \mu \mathrm{mol} \mathrm{L}^{-1}$ and $0.12 \mu \mathrm{mol} \mathrm{L}^{-1}$ at Sta. 66 and 20 , respectively. The nutrients were low or below detection at Sta. 10, 12, 14, 15,18 , and 26 for nitrate and phosphate (silicate not measured) (Table 2). Elevated nitrate $\left(0.13 \mu \mathrm{mol} \mathrm{L}^{-1}\right)$ and silicate $\left(2.4 \mu \mathrm{mol} \mathrm{L}^{-1}\right)$ concentrations were observed at Sta. 30 .

The remaining 12 stations (Sta. 3-5, 8, 9, 33-35, and 3639) had characteristic open ocean conditions, where surface salinities were highest $(\geq 35)$, and all three nutrients (nitrate, phosphate, silicate) were detectable, but measur- able only at Sta. $8\left(0.15 \mu \mathrm{mol} \mathrm{L}-1\right.$ and $0.94 \mu \mathrm{mol} \mathrm{L}^{-1}$ for phosphate and silicate, respectively). Nitrate, phosphate, or both were below the detection limits of standard colorimetric techniques at the other six stations (Sta. 3, 4, 5, 34, 38 , and 39). Silicate was $<1.0 \mu \mathrm{mol} \mathrm{L}^{-1}$ or undetectable at Sta. 5 and 39.

Qualitative observations - A brief explanation is presented here for some of the more interesting observations that were made of the phytoplankton community structure during the April-May 2003 transect. Our observations are limited to plankton $>5 \mu \mathrm{m}$ in size because of the pore size of the filter, represent a qualitative assessment rather than quantitative cell counts (see Methods), and were made during the second leg of the cruise only (Sta. 30-69).

In general, Trichodesmium spp. were more often observed as free filaments than colonies, and when colonies 
Table 3. Summary of depth profiles and surface samples. Asterisks designate the degree of PCR efficiency: samples without asterisk had $95-100 \%$ PCR efficiency, * indicates samples with efficiencies $<95 \%$, and $* *$ designates complete inhibition.

\begin{tabular}{|c|c|c|c|c|c|c|c|c|c|}
\hline \multirow[b]{2}{*}{$\begin{array}{l}\text { Station } \\
\text { ID }\end{array}$} & \multirow[b]{2}{*}{$\begin{array}{l}\text { Depth } \\
\text { (m) }\end{array}$} & \multirow[b]{2}{*}{$\begin{array}{c}\text { Temperature } \\
\left({ }^{\circ} \mathrm{C}\right)\end{array}$} & \multirow[b]{2}{*}{ Salinity } & \multicolumn{6}{|c|}{ Mean nifH gene copies $\mathrm{L}^{-1}$} \\
\hline & & & & $\begin{array}{l}\text { H. haukii- } \\
\text { Richelia }\end{array}$ & $\begin{array}{l}\text { R. clevei- } \\
\text { Richelia }\end{array}$ & $\begin{array}{l}\text { Trichodes- } \\
\text { mium spp. }\end{array}$ & $\begin{array}{c}\text { Group } \\
\text { A }\end{array}$ & $\begin{array}{c}\text { Group } \\
\text { B }\end{array}$ & $\begin{array}{c}\text { Group } \\
\text { C }\end{array}$ \\
\hline \multirow[t]{6}{*}{7} & 70 & 27.5 & 36.1 & $1.3 \times 10^{2 *}$ & $1.7 \times 10^{1}$ & $3.9 \times 10^{2 *}$ & $9.7 \times 10^{2}$ & $2.3 \times 10^{3}$ & $5.6 \times 10^{2 *}$ \\
\hline & 60 & 27.8 & 36.0 & $6.5 \times 10^{1 *}$ & $8.9 \times 10^{1}$ & $1.6 \times 10^{3 *}$ & $4.1 \times 10^{2}$ & $2.5 \times 10^{3}$ & $\mathrm{bd}^{*}$ \\
\hline & 50 & 28.2 & 35.8 & $2.0 \times 10^{2 *}$ & $8.7 \times 10^{1}$ & $1.3 \times 10^{3 *}$ & $1.4 \times 10^{3}$ & $1.4 \times 10^{3}$ & $8.6 \times 10^{1 *}$ \\
\hline & 30 & 28.2 & 35.7 & $1.6 \times 10^{4}$ & $2.4 \times 10^{3}$ & $9.3 \times 10^{4}$ & $6.5 \times 10^{3}$ & $1.0 \times 10^{3}$ & $5.4 \times 10^{4 *}$ \\
\hline & 20 & 28.2 & 35.4 & $2.7 \times 10^{4}$ & $5.2 \times 10^{3}$ & $1.3 \times 10^{5}$ & $5.2 \times 10^{3}$ & $9.1 \times 10^{3}$ & $1.1 \times 10^{5 *}$ \\
\hline & 10 & 28.2 & 35.1 & $3.9 \times 10^{4}$ & $5.4 \times 10^{3}$ & $5.1 \times 10^{4}$ & $1.7 \times 10^{3}$ & $9.7 \times 10^{3}$ & $8.6 \times 10^{4 *}$ \\
\hline \multirow[t]{6}{*}{13} & 60 & 26.9 & 36.1 & $2.2 \times 10^{4 *}$ & detected & $4.6 \times 10^{2}$ & detected & $1.9 \times 10^{2}$ & detected \\
\hline & 40 & 27.3 & 35.7 & $4.8 \times 10^{4 *}$ & $5.4 \times 10^{1}$ & $1.3 \times 10^{2 *}$ & $2.1 \times 10^{2}$ & $5.5 \times 10^{2}$ & detected \\
\hline & 30 & 27.5 & 35.2 & $6.2 \times 10^{4 *}$ & $9.5 \times 10^{1}$ & $2.0 \times 10^{2}$ & $5.5 \times 10^{1 *}$ & $3.5 \times 10^{2}$ & detected \\
\hline & 20 & 27.6 & 35.1 & $6.9 \times 10^{2}$ & $6.8 \times 10^{2}$ & $3.8 \times 10^{3}$ & detected* & $1.8 \times 10^{3}$ & $1.4 \times 10^{3}$ \\
\hline & 10 & 27.7 & 35.0 & $1.1 \times 10^{7}$ & $5.2 \times 10^{2}$ & $3.9 \times 10^{4}$ & $1.1 \times 10^{2 *}$ & $2.2 \times 10^{3}$ & $5.8 \times 10^{3}$ \\
\hline & 0 & 27.7 & 34.9 & $6.5 \times 10^{6 *}$ & $8.4 \times 10^{2}$ & $1.7 \times 10^{4}$ & $5.2 \times 10^{0 *}$ & $4.9 \times 10^{3}$ & $8.9 \times 10^{3}$ \\
\hline \multirow[t]{5}{*}{17} & 90 & 25.8 & 36.2 & $7.0 \times 10^{3 *}$ & bd & bd & $2.7 \times 10^{1}$ & detected & $4.6 \times 10^{2}$ \\
\hline & 75 & 26.0 & 36.1 & $6.1 \times 10^{4 *}$ & detected & detected & $4.8 \times 10^{2}$ & detected & $2.3 \times 10^{3}$ \\
\hline & 50 & 26.8 & 36.0 & $1.4 \times 10^{5}$ & detected & $\mathrm{bd}$ & bd & detected & $1.3 \times 10^{2}$ \\
\hline & 30 & 27.7 & 34.6 & $1.2 \times 10^{5}$ & $2.6 \times 10^{4}$ & $1.3 \times 10^{3}$ & $3.3 \times 10^{3}$ & $2.5 \times 10^{3}$ & $2.0 \times 10^{3}$ \\
\hline & 13 & 27.7 & 34.6 & $1.3 \times 10^{5}$ & $\mathrm{bd}$ & $9.3 \times 10^{1}$ & $2.6 \times 10^{3}$ & $\mathrm{bd}$ & $4.1 \times 10^{2}$ \\
\hline \multirow{6}{*}{25} & 90 & 26.0 & 36.9 & $2.4 \times 10^{4}$ & bd & detected & $1.6 \times 10^{2}$ & detected & detected \\
\hline & 65 & 27.0 & 36.2 & $1.9 \times 10^{4}$ & detected & $7.4 \times 10^{1}$ & $1.3 \times 10^{3}$ & $3.1 \times 10^{2}$ & detected \\
\hline & 45 & 26.9 & 36.2 & $3.5 \times 10^{4}$ & bd & $1.9 \times 10^{3}$ & $1.1 \times 10^{3}$ & $2.7 \times 10^{2}$ & detected \\
\hline & 30 & 26.9 & 36.1 & $2.4 \times 10^{5}$ & bd & $3.8 \times 10^{3}$ & bd & $\mathrm{bd}$ & bd \\
\hline & 15 & 27.7 & 30.4 & $7.2 \times 105$ & & detected & $7.6 \times 10^{2}$ & $4.3 \times 10^{1}$ & detected \\
\hline & 0 & 27.8 & 28.6 & $6.7 \times 100 *$ & detected $^{* *}$ & $\mathrm{bd}^{* *}$ & $\mathrm{bd}^{* *}$ & $\mathrm{bd}^{* *}$ & $\mathrm{bd}^{* *}$ \\
\hline \multirow[t]{6}{*}{31} & 88 & 25.8 & 36.5 & $1.1 \times 10^{3}$ & bd & $4.1 \times 10^{0}$ & bd & detected & detected \\
\hline & 70 & 26.2 & 36.3 & $2.8 \times 10^{3}$ & detected & $2.2 \times 10^{3}$ & bd & $3.8 \times 10^{3}$ & $7.1 \times 10^{4}$ \\
\hline & 60 & 26.5 & 36.2 & $2.8 \times 10^{4}$ & $8.6 \times 10^{0}$ & $7.7 \times 10^{3}$ & $1.6 \times 10^{2}$ & $1.6 \times 10^{3}$ & detected \\
\hline & 45 & 26.7 & 36.2 & $1.1 \times 10^{5}$ & detected & $2.0 \times 10^{3}$ & $1.0 \times 10^{1}$ & $3.0 \times 10^{3}$ & detected \\
\hline & 25 & 26.8 & 35.8 & $1.7 \times 10^{7}$ & $1.3 \times 10^{2 *}$ & $3.6 \times 10^{4}$ & detected* & & $5.2 \times 10^{4}$ \\
\hline & 10 & 27.5 & 34.3 & $2.3 \times 10^{5}$ & $6.0 \times 10^{1}$ & $1.4 \times 10^{4}$ & $1.0 \times 10^{2}$ & $3.4 \times 10^{2}$ & bd \\
\hline \multirow[t]{6}{*}{33} & 110 & 24.3 & 36.4 & $2.3 \times 10^{4}$ & bd & detected & detected & bd & $\mathrm{bd}$ \\
\hline & 90 & 25.6 & 36.4 & detected & $\mathrm{bd}$ & detected & $1.4 \times 10^{4}$ & $\mathrm{bd}$ & detected \\
\hline & 75 & 26.1 & 36.5 & $2.7 \times 10^{2}$ & detected & $3.0 \times 10^{3}$ & $1.9 \times 10^{5 *}$ & detected & detected \\
\hline & 50 & 26.1 & 36.5 & $9.4 \times 10^{2}$ & detected & $5.8 \times 10^{2}$ & $2.2 \times 10^{5}$ & $2.1 \times 10^{2}$ & $7.8 \times 10^{2}$ \\
\hline & 35 & 26.1 & 36.5 & $4.3 \times 10^{2}$ & detected* & $2.3 \times 10^{3 *}$ & $2.6 \times 10^{5 *}$ & $1.3 \times 10^{2}$ & $1.1 \times 10^{2}$ \\
\hline & 20 & 26.1 & 36.4 & $\mathrm{bd}^{* *}$ & $\mathrm{bd}^{* *}$ & $\mathrm{bd}^{* *}$ & detected $* *$ & detected* & $4.1 \times 10^{1 *}$ \\
\hline \multirow[t]{6}{*}{35} & 90 & 23.0 & 36.4 & detected & $\mathrm{bd}$ & detected & $\mathrm{bd}^{* *}$ & $\mathrm{bd}$ & detected \\
\hline & 70 & 25.5 & 36.4 & $2.7 \times 10^{2}$ & detected & $2.8 \times 10^{2}$ & $1.0 \times 10^{2 *}$ & $2.1 \times 10^{2}$ & $1.3 \times 10^{3}$ \\
\hline & 50 & 27.1 & 36.3 & $1.3 \times 10^{3}$ & detected & $2.7 \times 10^{3}$ & $1.1 \times 10^{4}$ & $8.1 \times 10^{3}$ & $7.8 \times 10^{3}$ \\
\hline & 35 & 27.2 & 36.2 & $3.2 \times 10^{3}$ & detected & $4.4 \times 10^{4}$ & $6.0 \times 10^{3}$ & $1.3 \times 10^{4}$ & $5.6 \times 10^{3}$ \\
\hline & 15 & 27.0 & 35.7 & $3.5 \times 10^{4}$ & $7.7 \times 10^{2}$ & $1.4 \times 10^{5}$ & $7.8 \times 10^{3}$ & $6.5 \times 10^{3}$ & $2.5 \times 10^{4}$ \\
\hline & 5 & 27.3 & 35.7 & $3.5 \times 10^{4}$ & $1.3 \times 10^{4}$ & $1.4 \times 10^{6 *}$ & $1.5 \times 10^{4}$ & $1.5 \times 10^{4}$ & $7.7 \times 10^{3}$ \\
\hline \multirow[t]{5}{*}{37} & 75 & 25.2 & 36.4 & $1.8 \times 10^{3}$ & $1.5 \times 10^{3}$ & $4.6 \times 10^{3}$ & $4.0 \times 10^{4}$ & $1.1 \times 10^{4}$ & detected \\
\hline & 45 & 27.3 & 35.9 & $9.7 \times 10^{3}$ & $3.1 \times 10^{3}$ & $4.2 \times 10^{5}$ & $9.3 \times 10^{4}$ & $1.3 \times 10^{6}$ & $4.6 \times 10^{4}$ \\
\hline & 30 & 27.4 & 35.9 & $3.3 \times 10^{4}$ & $1.1 \times 10^{4}$ & $2.2 \times 10^{5}$ & $7.4 \times 10^{4}$ & $6.6 \times 10^{5}$ & $6.1 \times 10^{4}$ \\
\hline & 15 & 27.4 & 35.9 & $4.0 \times 10^{4}$ & $6.2 \times 10^{4}$ & $2.0 \times 10^{6}$ & $2.3 \times 10^{5}$ & $4.9 \times 10^{5}$ & $1.4 \times 10^{5}$ \\
\hline & 5 & 27.4 & 35.9 & $1.7 \times 10^{4}$ & $8.4 \times 10^{3}$ & $8.1 \times 10^{4}$ & $1.2 \times 10^{4}$ & $2.6 \times 10^{5}$ & $6.2 \times 10^{3 *}$ \\
\hline \multirow[t]{6}{*}{58} & 80 & 26.3 & 36.2 & bd & detected** & bd & bd & $\mathrm{bd}$ & bd \\
\hline & 65 & 27.0 & 36.3 & $1.2 \times 10^{2}$ & bd & $\mathrm{bd}$ & $\mathrm{bd}$ & detected & detected \\
\hline & 45 & 27.0 & 36.0 & $1.3 \times 10^{2}$ & bd & detected & detected & detected & bd \\
\hline & 25 & 27.7 & 35.1 & $1.9 \times 10^{3}$ & bd & $\mathrm{bd}$ & & detected & $\mathrm{bd}$ \\
\hline & 10 & 27.6 & 31.5 & $9.1 \times 10^{2}$ & bd & detected & $\mathrm{bd}$ & $\mathrm{bd}$ & $\mathrm{bd}$ \\
\hline & 0 & 27.6 & 31.4 & $2.6 \times 10^{3}$ & $1.2 \times 10^{2}$ & $1.1 \times 10^{4}$ & bd & $\mathrm{bd}$ & $\mathrm{bd}$ \\
\hline
\end{tabular}


Table 3. Continued.

\begin{tabular}{|c|c|c|c|c|c|c|c|c|c|}
\hline $\begin{array}{l}\text { Station } \\
\text { ID }\end{array}$ & $\begin{array}{l}\text { Depth } \\
\text { (m) }\end{array}$ & $\begin{array}{c}\text { Temperature } \\
\left({ }^{\circ} \mathrm{C}\right)\end{array}$ & Salinity & \multicolumn{6}{|c|}{ Mean nifH gene copies $\mathrm{L}^{-1}$} \\
\hline \multirow[t]{4}{*}{69} & 70 & 26.5 & 36.2 & $2.5 \times 10^{3}$ & detected & $3.7 \times 10^{3}$ & detected & detected & detected \\
\hline & 45 & 26.9 & 36.1 & $1.0 \times 10^{5}$ & $\mathrm{bd}$ & $2.1 \times 10^{3}$ & bd & bd & $3.2 \times 10^{3}$ \\
\hline & 30 & 27.3 & 35.0 & $2.7 \times 10^{4}$ & $4.4 \times 10^{3}$ & $2.6 \times 10^{4}$ & $4.7 \times 10^{2}$ & $1.8 \times 10^{2}$ & $2.7 \times 10^{3}$ \\
\hline & 15 & 27.7 & 32.6 & $1.5 \times 10^{5}$ & $2.3 \times 10^{2}$ & $5.5 \times 10^{4}$ & $1.4 \times 10^{3 *}$ & $1.5 \times 10^{2}$ & $4.1 \times 10^{3}$ \\
\hline 4 & 10 & 26.7 & 36.3 & $\mathrm{bd}^{* *}$ & $\mathrm{bd}^{* *}$ & $\mathrm{bd}^{* *}$ & $\mathrm{bd}^{* *}$ & $\mathrm{bd}^{* *}$ & $\mathrm{bd}^{* *}$ \\
\hline 9 & 20 & 26.7 & 35.2 & $6.0 \times 10^{6}$ & $\mathrm{bd}$ & detected* & $5.6 \times 10^{1 *}$ & $5.5 \times 10^{2}$ & $7.0 \times 10^{4}$ \\
\hline 11 & 0 & 27.8 & 31.9 & $1.9 \times 10^{4} *$ & $\mathrm{bd}^{* *}$ & $2.5 \times 10^{2 *}$ & $3.4 \times 10^{3 *}$ & $6.8 \times 10^{2 *}$ & $4.1 \times 10^{4 *}$ \\
\hline 15 & 5 & 27.2 & 34.7 & $9.9 \times 10^{6}$ & $4.8 \times 10^{2}$ & $3.9 \times 10^{4}$ & $\mathrm{bd}^{*}$ & $2.9 \times 10^{3}$ & $1.4 \times 10^{1}$ \\
\hline 22 & 10 & 27.8 & 33.8 & $\mathrm{bd}^{*}$ & $\mathrm{bd}^{* *}$ & $\mathrm{bd} * *$ & $\mathrm{bd}^{* *}$ & $\mathrm{bd}^{* *}$ & $\mathrm{bd}^{* *}$ \\
\hline 27 & 10 & 27.6 & 33.4 & $6.0 \times 10^{6}$ & bd & $4.9 \times 10^{2}$ & detected & detected & $1.5 \times 10^{3}$ \\
\hline
\end{tabular}

were present these were typically embedded with diatom assemblages. For example, at Sta. 33, there were larger colonies of Trichodesmium observed at $20 \mathrm{~m}$ than $35 \mathrm{~m}$, however the colonies at $35 \mathrm{~m}$ were embedded with Mastogloia diatoms. Similar observations were recorded at $120 \mathrm{~m}$ at Sta. 30, where the colonies of Trichodesmium appeared moribund or degrading and were entangled with Mastogloia and other smaller pennate diatoms. More trichomes than colonies were observed at Sta. 27, 29, 30, 31, 32, 35, 36, 66, and 69; at Sta. 31 many of these were hormogonia. At Sta. 66 only free filaments were observed at $30 \mathrm{~m}$, and at Sta. 35 and 36 , more free filaments were noted down to $75 \mathrm{~m}$ and $110 \mathrm{~m}$, respectively.

At most stations free-living Trichodesmium spp. and symbiotic Richelia associated with $H$. hauckii and $R$. clevei were observed along with two other morphologies of cyanobacteria. These included coccoid cyanobacteria 5-7 $\mu \mathrm{m}$ in diameter and clusters of 8-16 oblong cyanobacterial cells (1-2 $\mu \mathrm{m}$ in diameter). Both morphologies were more commonly observed in the eastern stations (Sta. 4, 35, 36, and 37) and, in particular, at Sta. 7 and 9 in the southern part of the transect (Fig. 1). The Calothrix sp. symbiont that attaches to the spines of the Chaetoceros sp. diatom was never observed.

Cell length, cell diameter, and the number of Richelia trichomes observed per diatom host varied as did the integrity of the trichomes and the hosts. At some stations (Sta. 7, 9, 15, 27, 28, 29, 66, and 67) the vegetative cells of Richelia were comparatively large, comprising 3-4 cells and a terminal heterocyst. These were also associated with long chains of $H$. hauckii (up to 100 cells). At other stations (Sta. 25, 31, and 35) and particularly at deeper depths (Sta. 22, $100 \mathrm{~m}$; Sta. 28, $60 \mathrm{~m}$ and $45 \mathrm{~m}$ ), the Richelia appeared only as a terminal heterocyst. In addition, when the Richelia trichome was short, the $H$. hauckii did not form chains, and often the host diatom frustules appeared compromised (broken). At Sta. 31, we observed that the H. hauckii cells at $100 \mathrm{~m}$ appeared moribund, the frustules were empty of chloroplasts, and their symbiotic Richelia trichomes had no vegetative cells. At Sta. 69, H. hauckii were associated with Richelia and appeared to dominate the biomass, but host chains appeared compressed, short, and enveloped in a matrix.

There were a few stations (Sta. 32 and 36) where $R$. clevei with Richelia symbionts were more frequently observed than the H. hauckii-Richelia symbioses. At Sta. 30, 31, 33, 41, 58, and 67 few $R$. clevei cells were observed, and most cells were devoid of symbionts and chloroplasts. It should be noted that the $R$. clevei-Richelia phylotype was low or below detection in the QPCR study (Table 3; see Vertical distributions and Horizontal distributions below) at most depths of Sta. 31, 33, and 58. Empty $R$. clevei hosts were typically observed at the deeper depths $(60-100 \mathrm{~m})$ with the exception of the $0 \mathrm{~m}$ and $10 \mathrm{~m}$ samples from Sta. 58 and Sta. 31, respectively. At Sta. 67, the $R$. clevei hosts in the surface samples $(5 \mathrm{~m}$ and $20 \mathrm{~m})$ were composed of large chloroplasts and had symbiotic Richelia; however, the host population at depth was empty. Up to 6-10 trichomes (Sta. 35 and 37) of Richelia cells with enlarged vegetative cells were observed associated with a single Rhizosolenia filament; however, this was rare, and usually 2-4 trichomes of Richelia were present in one Rhizosolenia cell.

At the few stations (Sta. 19, 22, and 25) where surface salinities were $<30$ the community structure drastically changed. Diatoms belonging to the genera Coscinodiscus, Eucampia, Thalassiosira, Thalassionema, Skeletonema, and Pseudo-nitzchia were dominant in the surface waters. The larger dinoflagellate, Ceratium, was also common. At all stations, small $(<10 \mu \mathrm{m}$ in cell diameter $)$ pico-eukaryotes were abundant throughout the euphotic zone and sometimes were found within Trichodesmium sp. colonies.

Phylogenetic analyses-A 359 bp fragment of nifH was amplified, cloned, and sequenced from 21 samples to assess nifH diversity. The majority $(103,81 \%)$ of the sequences (127 total) were $>97 \%$ identical (BLASTN) to Trichodes- 
mium or Katagnymene spp. nifH sequences. The sequence AO_5202A67 (accession DQ273169) obtained from a sample from $30 \mathrm{~m}$ at Sta. 13 was $99 \%$ identical (BLASTN) to a nifH sequence from an uncultured marine bacterium (accession AY896461; Langlois et al. 2005) previously reported from the WTNA. The same sequence was $90 \%$ identical (BLASTN) to the $n i f H$ sequence from Cyanothece spp. ATCC 51142 (accession no. AF003336). This sequence type is here defined as Group C. Twenty-three (18\%) other sequences were $>95 \%$ identical (BLASTN) to unidentified environmental noncyanobacterial nifH sequences.

Quantitative $P C R$-The relationship between $\mathrm{C}_{\mathrm{t}}$ and gene copy number was linear from 1 to $10^{8}$ target molecules for all of the TaqMan primer and probe sets (Fig. 4). $r^{2}$ values for linear regressions were $>0.98$. To test the cross-reactivity between primers and probes and closely related nontarget nifH phylotypes, standards of one target were probed with a nontarget primer/probe set. These cross-reactivity experiments also test how specific one primer and probe set are at distinguishing each target phylotype, i.e., Richelia associated with $H$. hauckii versus the Richelia associated with $R$. clevei. Although $R$. cleveiRichelia $(R-R)$ standards did amplify with the H. hauckiiRichelia $(H-R)$ primer and probe set, the $\mathrm{C}_{\mathrm{t}}$ values were 23 times greater (less gene copies) than the $\mathrm{C}_{\mathrm{t}}$ values of the $H-R$ target at the same template concentration (Fig. 4A). In addition, the last two standards (approximately 1 and 10 gene copies/reaction), did not amplify $\left(C_{t}=45\right)$. No cross-reaction was detected when Chaetoceros-Calothrix ( $C-C$ ) standards were tested with the $R-R$ or $H-R$ primers and probes (Fig. 4A).

The unicellular Group B standards did not amplify with the primers and probes of Group $C\left(C_{t}=45\right.$; Fig. 4B). There was, however, nonlinear amplification using the Group A standards and Group C primers (Fig. 4B). The $\mathrm{C}_{\mathrm{t}}$ values for Group A ranged from undetected (no amplification; $C_{t}=45$ ) to five orders of magnitude less than the expected values if Group $\mathrm{C}$ standards were run with the Group C primers and probes (Fig. 4B).

Each sample was tested for inhibition of amplification by the addition of internal standards. The amplification efficiency (amplification of target plasmid alone versus plasmid plus sample) was $<95 \%$ in $57(14 \%)$ and completely inhibited in $23(5.8 \%)$ of the 396 total PCR reactions (designated with * for $<95 \%$ efficiency and $* *$ for completely inhibited in Table 3 ). The primer and probe sets that targeted the unicellular Group B were the most efficient; low PCR efficiencies were observed in seven
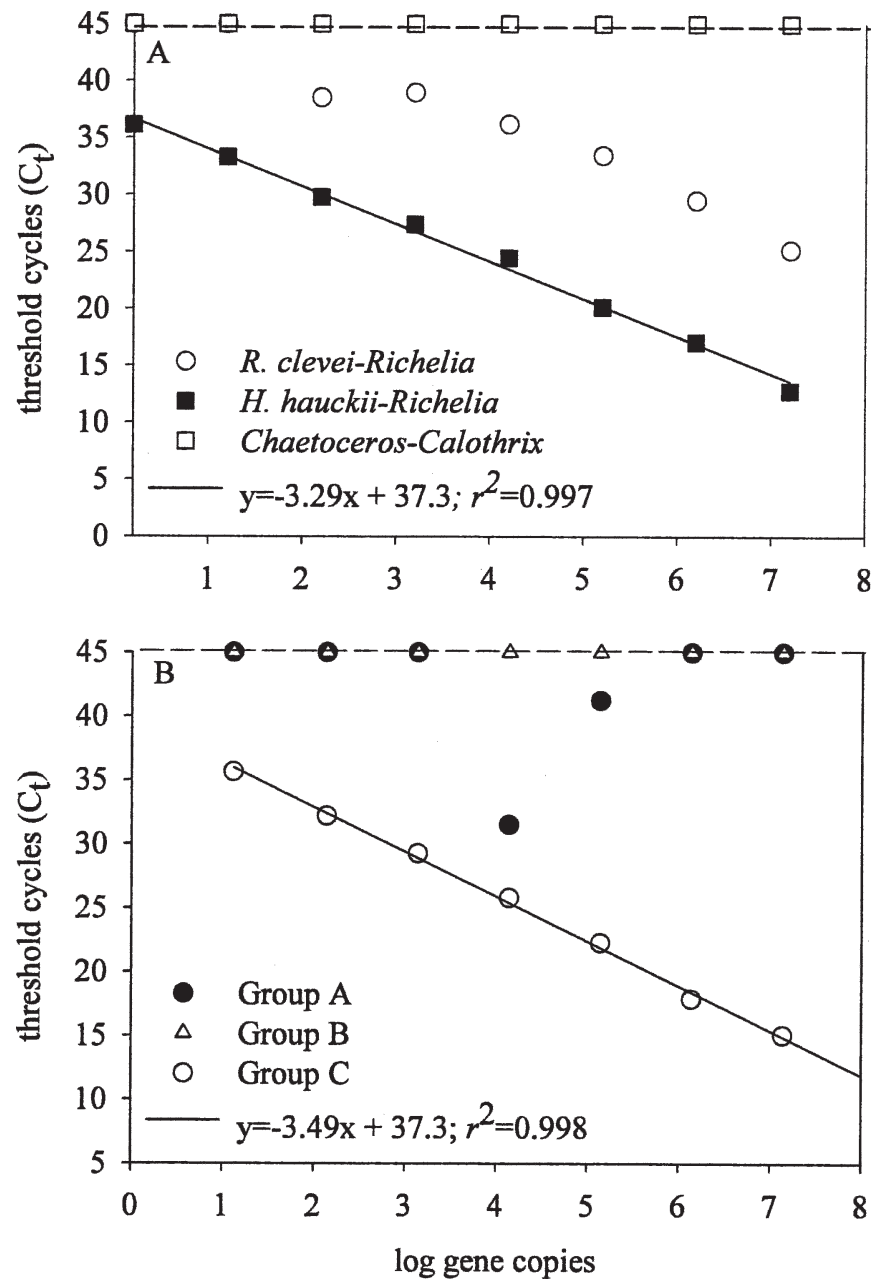

Fig. 4. Representative standard curves for QPCR and results from specificity experiments. (A) The standard curve and calculated regression obtained for the Hemiaulus-Richelia QPCR primers and probes and the cross reactivity when the HemiaulusRichelia primers and probes were run with Rhizosolenia-Richelia and Chaetoceros-Calothrix standards. (B) The standard curve and calculated regression for group $\mathrm{C}$ primers and probes and the results from the cross-reactivity experiment when group $\mathrm{A}$ and group B standards were assayed with the group C primer and probes. Dashed line designates below the detection of the instrument $\left(\mathrm{C}_{\mathrm{t}}=45 ;<1\right.$ gene copy $\left.\mathrm{L}^{-1}\right)$.

samples (10\%). QPCR reactions using the Group A oligonucleotides were the least efficient; 20 samples (30\%) were $<95 \%$ efficient in their PCR reactions. The QPCR reactions targeting $H-R, R-R$, Trichodesmium, and unicel-

Table 4. Summary of PCR efficiency for samples sorted into three depth bins: shallow ( $<20 \mathrm{~m})$, intermediate $(20-50 \mathrm{~m})$, and deep $(>50 \mathrm{~m})$. Efficiencies are reported as percentages $(\%)$ with standard errors.

\begin{tabular}{cccccccc}
\hline \hline $\begin{array}{c}\text { Depth } \\
\text { Interval }\end{array}$ & $\begin{array}{c}\text { Number of } \\
\text { samples }\end{array}$ & $\begin{array}{c}\text { H. haukii- } \\
\text { Richelia }\end{array}$ & $\begin{array}{c}\text { R. clevei- } \\
\text { Richelia }\end{array}$ & $\begin{array}{c}\text { Tricho- } \\
\text { desmium spp. }\end{array}$ & Group A & Group B & Group C \\
\hline $\begin{array}{c}\text { Surface }(0-20 \mathrm{~m}) \\
\text { Intermediate }(20-\end{array}$ & 26 & $71.8 \pm 8.4$ & $77.5 \pm 7.9$ & $70.5 \pm 7.9$ & $69.5 \pm 7.6$ & $86.1 \pm 6.1$ & $85.1 \pm 6.0$ \\
$50 \mathrm{~m})$ & 16 & $97.0 \pm 1.1$ & $99.0 \pm 0.6$ & $96.0 \pm 2.2$ & $97.0 \pm 1.5$ & $100 \pm 0.2$ & $97.2 \pm 1.8$ \\
Deep $(>50 \mathrm{~m})$ & 23 & $95.2 \pm 1.3$ & $100 \pm 0.2$ & $96.4 \pm 1.6$ & $93.3 \pm 4.4$ & $100 \pm 0.2$ & $91.1 \pm 4.6$ \\
\hline
\end{tabular}


lular Group C were inhibited in 16, 10, 15, and 12 samples, respectively. It should be noted that low amplification efficiencies for all of the primers and probes were observed in seven samples (* and **; Table 3 ). When all the data were pooled and sorted into three depth categories $(0-20$, $20-50$, and $>50 \mathrm{~m}$ ), the amplification efficiency was highest in the intermediate and deeper samples (Table 4).

Vertical distributions - The depth distribution of all target nifH phylotype abundances was examined at 10 stations (Fig. 3A-J; Table 3). Generally, nifH gene concentrations were highest in the upper water column $(0$ $30 \mathrm{~m})$ and decreased with depth. The $H-R$ symbioses were the most abundant phylotype $\left(10^{3}-10^{7}\right.$ nifH gene copies $\mathrm{L}^{-1}$ ) in 6 of the 10 depth profiles (Fig. 3A-C,E-G; Table 3). At Sta. 25, which was characterized as a low surface salinity station, the $H$ - $R$ nif $H$ gene copy abundance $\left(\mathrm{L}^{-1}\right)$ was one to five orders of magnitude more abundant than all of the other targets at each depth (Figs. 3A; Table 3). The highest abundance of $H-R$ nifH gene copies $\left(>10^{5}\right)$ were recorded at Sta. 13, 17, 25, 31, and 69 (Fig. 3A,C,E-G; Table 3). At Sta. 13, estimates were higher at $10 \mathrm{~m}\left(1.1 \times 10^{7}\right.$ nif $H$ gene copies $\left.\mathrm{L}^{-1}\right)$ than the surface $\left(6.5 \times 10^{6}\right.$ nifH gene copies $\left.\mathrm{L}^{-1}\right)$ for $H-R$ (Fig. 3E). A similar pattern of subsurface maxima for the $H-R$ symbioses were also recorded at Sta. 17, 25, 31, 33, 37, and 69 , where the maximum number of gene copies $\mathrm{L}^{-1}$ was usually coincident with the pycnocline where sinking cells probably accumulate (Fig. 3A,C,F,G,H,J; Table 3).

Trichodesmium spp. were typically the second most abundant nifH phylotype in the depth profiles where there was intermediate to high surface salinity (Sta. 7, 17, 31, 33, and 35) (Fig. 3D,F-I; Table 3). At Sta. 69, which had a low surface salinity (26.4), the Trichodesmium spp. nifH was the second most abundant phylotype in the $15-\mathrm{m}$ sample, which was below the freshwater lens $\left(5.5 \times 10^{4}\right.$ nifH gene copies $\mathrm{L}^{-1}$ ), and at Sta. 58, Trichodesmium spp. were approximately one order of magnitude greater than the $H$ $R$ and the unicellular cyanobacterial groups (A, B, and C), which were below detection in the upper water column samples (Fig. 3B,C; Table 3). At Sta. 37, nifH estimates for Trichodesmium spp. showed a subsurface maximum at $15 \mathrm{~m}\left(2.0 \times 10^{6}\right.$ nif $\mathrm{H}$ gene copies $\left.\mathrm{L}^{-1}\right)$ and was most similar to the distribution of Group B nifH in deeper waters (Fig. 3J). At the low salinity station (Sta. 25) Trichodesmium spp. was undetected within the freshwater lens, but increased to $3.8 \times 10^{3}$ gene copies $\mathrm{L}^{-1}$ when salinity sharply increased at $30 \mathrm{~m}$ (Fig. 3A). The nifH $H$-R phylotype was undetected in two of the 56 depth profile samples, and Trichodesmium was below detection in seven of the 56 samples (Table 3). In one case (Sta. 25) this was because of PCR inhibition of both probe sets (Table 3).

The Chaetoceros-Calothrix symbioses were undetected in all surface and depth samples, and the $R-R$ symbioses were the least abundant nifH phylotype in the depth profiles (Fig. 3A-J; Table 3). In 16 samples, the nifH of $R-R$ was below detection $\left(<1\right.$ gene copy $\left.\mathrm{L}^{-1}\right)$, including five samples from the upper water column $(<20 \mathrm{~m})$ (Table 3$)$. Only one of these 16 samples had full PCR inhibition (indicated by ** in Table 3). An additional 15 samples had detectable

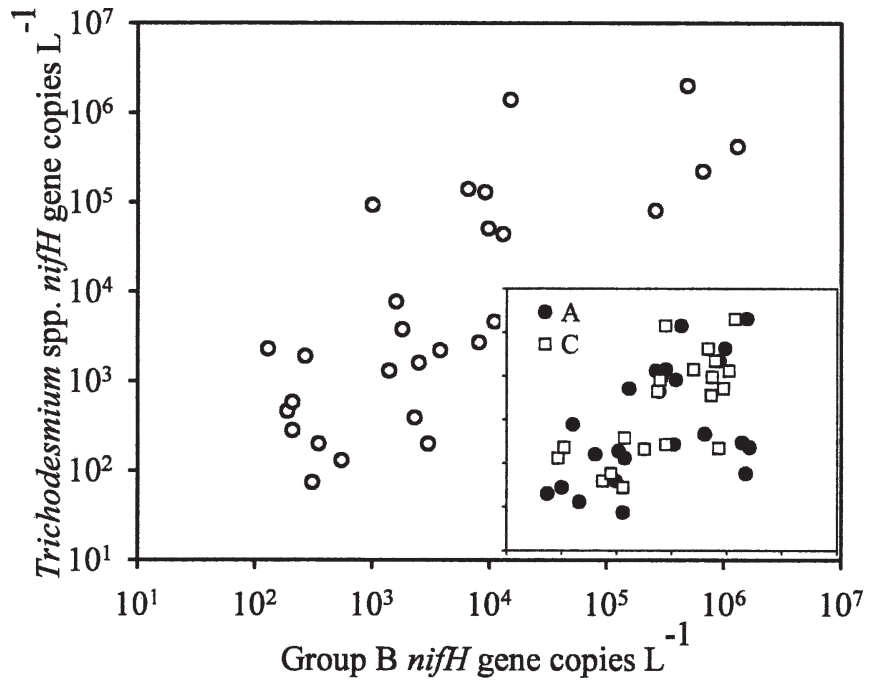

Fig. 5. The relationship between the log of nifH gene copy estimates for Trichodesmium and Group B nifH at the high salinity stations. Inset is the relationship between Trichodesmium and Groups $\mathrm{A}$ and $\mathrm{C}$ where scales in axes are the same as in larger graph.

nifH for the $R$ - $R$ symbioses, however these were not quantifiable (see Methods), and one of the nine were from shallower depths $(<20 \mathrm{~m})$. The highest abundance for the $R$ - $R$ symbioses was recorded at Sta. 37, where a subsurface maximum was detected at $15 \mathrm{~m}\left(6.2 \times 10^{4}\right.$ gene copies $\left.\mathrm{L}^{-1}\right)$, and gene copies decreased with depth to $75 \mathrm{~m}$ (Fig. 3J). Although, the $R-R$ symbioses was not as abundant as the other phylotypes, it was detected at higher values $\left(10^{1}-10^{3}\right.$ gene copies $\mathrm{L}^{-1}$ ) at most depths from samples collected at Sta. 7 and 13 (Fig. 3D,E; Table 3).

The highest nifH gene abundances $\left(4.1 \times 10^{1}\right.$ to $1.3 \times$ $10^{6}$ nifH gene copies $\mathrm{L}^{-1}$ ) for unicellular Groups $\mathrm{A}, \mathrm{B}$, and $\mathrm{C}$ were recorded at the high surface salinity stations (Fig. 3D-J; Table 3). Typically, Group B had the highest abundances of the three unicellular groups and often was as abundant as Trichodesmium spp. There were a few exceptions. At Sta. 33, Group A was the most abundant nifH phylotype in the water column down to $90-\mathrm{m}$ depth (Fig. 3H; Table 3). Secondly, at 2-4 depths of Sta. 7, 13, $17,31,35$, and 69 , unicellular Group $\mathrm{C}$ was one to two orders of magnitude greater than Groups A and B (Fig. 3C-I; Table 3). At Sta. 25 and 69, nifH gene copy estimates for unicellular Group A and Group C, respectively, were comparable to those of the larger diazotrophs. Unicellular cyanobacterial groups were detected in 3-4 depths of the low and intermediate surface salinity stations (Sta. 25 and 69) and were comparable gene copy numbers to Trichodesmium spp (Fig. 3A,C), however, these were at the depths below the freshwater lens $(0 \mathrm{~m})$. All unicellular cyanobacterial groups were below detection within the plume at Sta. 25 and 47, but the surface sample of Sta. 25 was fully inhibited in the QPCRs (**; Table 3).

When all values for depth profiles were pooled and divided into the three salinity categories (low, meso, high), within the high salinity $(\geq 35)$ data, there was a significant 
and positive correlation between Trichodesmium sp. nifH gene copy abundance and unicellular Group B (Pearson correlation, $p<0.001, r^{2}=0.59$ ) (Fig. 5). There was a significant, but weaker relationship between Trichodesmium and Groups $\mathrm{A}$ and $\mathrm{C}$ nifH gene copies (Pearson correlation, $p=0.0002, r^{2}=0.35-0.42$ ) (Fig. 5). There was no relationship between Trichodesmium and the diatomdiazotrophic symbioses or the symbioses with any of the unicellular phylotypes.

One-way ANOVAs were performed on the pooled and sorted depth profile data to determine differences in nifH abundance for one individual phylotype and between the six different phylotypes. Only the $H-R$ populations were significantly $(p<0.01)$ different. For example, the mean nif $H$ gene copy abundance $\left(8.0 \times 10^{5}\right.$ nif $H$ gene copies $\left.\mathrm{L}^{-1}\right)$ for the $H-R$ population within the mesohaline conditions was significantly (Kruskal-Wallis, $p=0.004$ ) higher than the estimates of the $H-R$ symbioses within the high and low salinity regimes. In addition, the $H-R$ nifH gene copy abundance in the intermediate salinity samples were significantly (Kruskal-Wallis, $p<0.001$; Holm-Sidak method, $p<0.002$ ) higher from all other phylotypes. Although there was a statistically significant difference (Kruskal-Wallis, $p=0.02$ ) between the phylotypes nifH gene copy abundance in the high salinity samples, $H-R$ was only considered significantly (Holm-Sidak method, $p<$ 0.001 ) higher in gene copy abundance than the $R$ - $R$ symbioses.

Horizontal distributions - In order to visualize the influence of the Amazon River plume on the distribution of the various diazotrophs we examined each target's nifH gene copy estimate as a function of latitude and longitude from 20 surface or shallow depth $(<20 \mathrm{~m})$ samples (Fig. 2C,D; Table 3). For those samples that were detected in two of the three replicates (detected, not quantifiable: see Methods), the total gene copies were estimated assuming 1 gene copy $\mathrm{L}^{-1}$ detection limit. The $C$ - $C$ symbioses nifH phylotype was not detected in any of the 10 surface samples tested (10 of 20 samples), were never observed by microscopy in our samples, and therefore were not included in the analyses. The geographical distribution of the nifH gene abundances for each target was analyzed with respect to salinity as estimated from the monthly composites of diffusion coefficients (Fig. 2A-D).

The $H-R$ symbioses were the most abundant target in 10 of the surface-water samples (50\%). The $H$ - $R$ phylotypes penetrated the low salinity surface lens at Sta. 25 and 47 $\left(8^{\circ} \mathrm{N}, 54^{\circ} \mathrm{W}\right)$ where $n i f H$ gene copies $\mathrm{L}^{-1}$ were 6.7 and $1.0 \times$ $10^{4}$, respectively (Fig. 2C,D; Table 3). Both stations were sampled in May 2003 and had lower surface salinities $(>30)$ in the May monthly composite and the salinity measured during the CTD cast (Fig. 2B,D; Table 3). There was a significant and positive correlation between surface salinity and the surface nifH abundance for the $H-R$ symbioses (Pearson correlation, $r^{2}=0.589, p=$ 0.02 ).

Some of the highest mean surface abundances $\left(1.4 \times 10^{4}\right.$ to $6.0 \times 10^{6}$ nif $H$ gene copies $\mathrm{L}^{-1}$ ) for the $H-R$ symbioses were recorded at mesohaline and high salinity stations
(Sta.11 and 9, respectively) in the southern region of the cruise transect (Fig. 2A-C; Table 3). Although the $H-R$ gene copy abundance in the high surface salinity samples was generally high, these were not considered significantly different than the other phylotypes. The $H-R$ symbioses in the surface of the mesohaline stations, however, was considered significantly (Holm-Sidak method, $p=0.001$ ) higher than the abundances of all of the other phylotypes. In addition, the $H-R$ in the mesohaline was considered significantly (Kruskal-Wallis, $p=0.045$ ) higher than the abundance estimates for $H-R$ in the low salinity samples.

Although Sta. 11 and 9 were sampled in April and showed no evidence of low salinity in the composite images or with salinity measures from the CTD, at Sta. 8, which was $<50 \mathrm{~km}$ from Sta. 9, concentrations of phosphorous $\left(0.15 \mu \mathrm{mol} \mathrm{L}^{-1}\right)$ and silicate $\left(0.94 \mu \mathrm{mol} \mathrm{L}^{-1}\right)$ were anomalously high (Fig. 2C; Table 2). In addition, the $H-R$ phylotype dominated $\left(>10^{3}\right.$ nifH gene copies $\left.\mathrm{L}^{-1}\right)$ the surface samples in the northern regions of the cruise where monthly composites predicted lower to intermediate salinities (Fig. 2A-C). Compared with the other phylotypes, the $H-R$ symbioses were comparable or lower in nifH gene copy abundance abundances $\left(\mathrm{L}^{-1}\right)$ in the surface samples of the easternmost stations (Sta. 33, 35, and 37) (Fig. 2C,D; Table 3).

The $R-R$ symbioses, Trichodesmium, and, especially, unicellular Groups A, B, and C showed an increase in mean surface nifH abundances with distance from the plume influence (Fig. 2A-D). For example, the highest surface nifH abundance for $R-R$ symbioses, Trichodesmium, and Group A were recorded at the northeastern station (Sta. 35 ), where nifH target concentrations averaged $1.3 \times 10^{4}$, $1.4 \times 10^{6}$, and $1.5 \times 10^{4}$ nifH gene copies $\mathrm{L}^{-1}$, respectively (Fig. 2C,D; Table 3). Group B nifH was the most abundant phylotype $\left(2.6 \times 10^{5}\right.$ nif $H$ gene copies $\left.\mathrm{L}^{-1}\right)$ of all targets at Sta. 37 (Fig. 2C,D; Table 3). Unicellular Group $\mathrm{C}$ had the highest surface abundances at Sta. 28, where $1.3 \times 10^{4}$ nifH gene copies $\mathrm{L}^{-1}$ were observed and coincided with a lower salinity (Fig. 2B,D). A significant difference in mean values among pooled surface estimates of $n i f H$ gene copy abundance for the $R-R$ symbioses was found between the surface salinity regimes (one-way Kruskal-Wallis, $p<0.001$ ). A similar result was found for the surface Trichodesmium populations (KruskalWallis, $p=0.023$ ), but not for the unicellular groups (A, $\mathrm{B}, \mathrm{C})$.

Between $11-12{ }^{\circ} \mathrm{N}$ and $52-53{ }^{\circ} \mathrm{W}$ (station 4, 33), few diazotrophs of any phylotype were detected (Fig. 2C,D; Table 3); Groups B and C were detected at low abundances in the surface sample of station 33 (41 nifH gene copies $\mathrm{L}^{-1}$ ). Stations 4 and 33 were sampled in April and May, respectively, and station 4 was less influenced by the plume (Fig. 2A,B). Station 33 had decreased values of salinity in the monthly composite (Fig. 2B), but the salinity recorded by the CTD remained high. Amplification of all but 2 of the samples from these stations was fully inhibited.

Four stations (Sta. 22, 25, 47, and 58) northwest $\left(7-9^{\circ} \mathrm{N}\right.$ and $54-56^{\circ} \mathrm{W}$ ) of the Amazon River mouth also had low abundances of all diazotrophic targets (Fig. 2C,D; Table 3). These stations were characterized as low to in- 
termediate salinity stations with the CTD and in the monthly composite (Fig. 2B; Table 3). Each target was below detection at Sta. 22, however the QPCR reactions were fully inhibited for all primer and probe sets (**; Table 3). The three unicellular cyanobacterial groups were below detection at an additional three stations (Sta. 25, 47, and 58), one of which had poor PCR efficiency (Fig. 2D; Table 3). The $R-R$ symbioses were undetected at two of the latter three stations, and were below detection in an additional five surface samples (Sta. 4, 9, 17, 27, and 33) (Fig. 2C; Table 3). Trichodesmium and $H$ - $R$ symbioses had similarly low abundances $\left(10^{0}-10^{4}\right.$ nifH gene copies $\mathrm{L}^{-1}$ ) within this region of the cruise transect (Fig. 2C; Table 3).

\section{Discussion}

In open ocean environments, Trichodesmium spp. are usually considered largely responsible for a major fraction of $\mathrm{N}_{2}$ fixation (Karl et al. 2002; Capone et al. 2005) although other groups of diazotrophs can be abundant. In this study, we used a real-time QPCR approach for estimating the abundance of Trichodesmium spp. and six other diazotrophic populations in the WTNA, including three symbiotically associated cyanobacteria, and three other unicellular groups (Groups A, B, and C). We found that the other groups, in particular the heterocystous cyanobiont $R$. intracellularis associated with $H$. hauckii diatoms, were equivalent in and often exceeded the abundance of Trichodesmium spp. and all of the other phylotypes. The nifH gene copy abundance estimates for Richelia associated with $H$. hauckii diatoms were significantly higher $(p<0.01)$ in both vertical and horizontal profiles, suggesting a distinct advantage by this population over the others. In addition, at several stations the unicellular cyanobacterial groups were abundant and collectively exceeded the abundances of Trichodesmium spp.

The detection limit of the QPCR method was similar $(\sim 1$ gene copy $\mathrm{L}^{-1}$ ) to limits previously reported (Suzuki et al. 2000; Short et al. 2004; Church et al. 2005a). Crossreactivity tests of the primer and probe sets for closely related targets (i.e., the heterocystous or unicellular groups), showed that there was cross-reaction, but the PCR efficiencies for nontargets were significantly reduced, nonlinear, and did not affect the estimation of target gene copy estimates for the target genes unless the nontarget was present in abundances exceeding $10^{3}$ copies $\mathrm{L}^{-1}$, which was never observed. There were several samples fully or partially inhibited by all primer and probe sets, and many of these were from samples within the influence of the plumes where CDOM was high; additionally, high abundances of diatoms were observed by microscopy. We assumed that CDOM and other chemical inhibitors were carried over in the DNA extraction and caused the observed inhibitions in the QPCRs.

The data were collected during a period of heightened flow from the Amazon River. Monthly composites of SeaWiF imagery showed that the Amazon River plume ranged between $0-20^{\circ} \mathrm{N}, 60-48^{\circ} \mathrm{W}$. The April and May composites were used to track the signature of the Amazon River outflow and when combined with the estimates of nif $H$ gene copies $\mathrm{L}^{-1}$ the effect of the freshwater lens on the geographical distribution of certain diazotrophs in the WTNA can be seen. As expected, there were higher nutrient concentrations in the low salinity surface samples (Table 2), and most of the target diazotrophs were not detected. One notable exception was the Richelia associated with $H$. hauckii, which was present at two surface samples collected within the plume. To a lesser extent, the R. cleveiRichelia symbioses were also present, however, abundance estimates were lower (1-102 nifH gene copies $\left.\mathrm{L}^{-1}\right)$. These areas of high surface nutrient concentrations, especially silicates $\left(2.0-10.5 \mu \mathrm{mol} \mathrm{L}^{-1}\right)$ and presumably Fe, may have been key factors for promoting the growth of the diatomdiazotroph symbioses.

The $H$. hauckii-Richelia abundances were similar to those previously reported from microscopic observations in the same area of the WTNA (Villareal 1994; Carpenter et al. 1999; Janson et al. 1999). For example, at several station, the QPCR estimates for H. hauckii-Richelia symbioses were $10^{6}-10^{7}$ copies $\mathrm{L}^{-1}$, which were similar to the abundances reported from cell counts $\left(>10^{6}\right.$ heterocysts $\mathrm{L}^{-1}$ ) for a $H$. hauckii-Richelia bloom previously observed in the same vicinity of the WTNA $\left(8^{\circ} \mathrm{N}, 45^{\circ} \mathrm{W}-10^{\circ} \mathrm{N}\right.$, $50^{\circ} \mathrm{W}$ ) (Carpenter et al. 1999). Villareal (1994) examined Hemiaulus spp. from the Caribbean Sea and southwest North Atlantic Ocean and found that 91-100\% of Hemiaulus hosts contained Richelia, and this symbiosis was 5-254 times more abundant than the RhizosoleniaRichelia symbioses. The H. hauckii-Richelia symbioses were the dominant phylotype in six of the 10 depth profiles and 10 of the 20 surface samples, suggesting that this symbiosis had a competitive advantage over the other two symbiotic associations and the free-living diazotrophic groups in this area at the time of sampling.

In laboratory and field experiments of symbiotic $R$. clevei and $H$. hauckii, respectively, the growth rate of symbiotic $H$. hauckii exceeds that of symbiotic $R$. clevei (Villareal 1989; 1990). The higher abundances of the $H$. hauckii-Richelia that we observed may be attributable to higher growth rates or higher nutrient uptake rates by this DDA. The nutrient kinetics, i.e., silicate uptake rate, of the DDAs is unknown. The smaller size of a $H$. hauckii diatom suggests a potential competitive advantage over the larger $R$. clevei hosts for nutrients, including dissolved silicates.

Another important factor in the distribution of symbioses is symbiont availability (Van Oppen et al. 2001). Richelia symbionts are transferred vertically from host diatom to daughter cells during host replication (Taylor 1982; Villareal 1989; 1990). However, hosts devoid of symbionts (Foster, pers. obs.) and free-living trichomes of Richelia have been observed (Gómez et al. 2005), which suggests a horizontal transmission of symbionts from the environment. These DDAs are considered highly specific (Janson et al. 1999) meaning that one Richelia strain associates with only one diatom host. Thus, when symbionts are transferred horizontally, the specific strain must be present and available. The nifH phylotype of Calothrix sp. was undetected in all samples tested and was 
Table 5. Summary of estimated $\mathrm{N}_{2}$ fixation for each phylotype. Abundances are reported as median nifH gene copy $\mathrm{L}^{-1}$ in each salinity category and cell specific rates are as reported previously in the literature.

\begin{tabular}{|c|c|c|c|c|c|c|c|}
\hline \multirow[b]{3}{*}{ Phylotype } & \multirow{3}{*}{$\begin{array}{l}\text { Cell-specific } \\
\text { rate (fmol } \\
\mathrm{N} \text { cell-1 } \\
\left.\mathrm{h}^{-1}\right)\end{array}$} & \multicolumn{2}{|c|}{ Low salinity (24.3-31.0) } & \multirow{2}{*}{\multicolumn{2}{|c|}{ Intermediate salinity (31.1-34.9) }} & \multirow{2}{*}{\multicolumn{2}{|c|}{ High salinity $(\geq 35)$}} \\
\hline & & \multirow{2}{*}{$\begin{array}{c}* \text { Abundance } \\
(\text { nifH } \\
\left.\text { copy } \mathrm{L}^{-1}\right)\end{array}$} & \multirow{2}{*}{$\begin{array}{c}\mathrm{N}_{2} \text { fixation } \\
(\text { fmol } \\
\left.\mathrm{L}^{-1} \mathrm{~d}^{-1}\right)\end{array}$} & & & & \\
\hline & & & & $\begin{array}{l}\text { *Abundance } \\
\left(\text { nif } H \text { copy } \mathrm{L}^{-1}\right)\end{array}$ & $\begin{array}{l}\mathrm{N}_{2} \text { fixation (fmol } \\
\left.\mathrm{L}^{-1} \mathrm{~d}^{-1}\right)\end{array}$ & $\begin{array}{l}\text { *Abundance } \\
\left(\text { nifH copy } \mathrm{L}^{-1}\right)\end{array}$ & $\begin{array}{c}\mathrm{N}_{2} \text { fixation } \\
\left(\mathrm{fmol} \mathrm{L}^{-1} \mathrm{~d}^{-1}\right)\end{array}$ \\
\hline $\begin{array}{c}\text { Unicellular } \\
\text { Groups } \\
(\mathrm{A}, \mathrm{B}, \mathrm{C})\end{array}$ & $1.3-29.0 \dagger \dagger \S$ & bd & na & $4.5 \times 10^{3}$ & $\begin{array}{l}5.6 \times 10^{3}-1.8 \times 10^{4} \\
\quad(0.1-0.2)\end{array}$ & $9.5 \times 10^{3}$ & $\begin{array}{l}1.3 \times 10^{4}-4.0 \times 10^{4} \\
(1.7-1.8)\end{array}$ \\
\hline Trichodesmium & $20 \%$ & bd & na & $1.3 \times 10^{3}$ & $2.6 \times 10^{4}(0.3)$ & $3.7 \times 10^{3}$ & $7.4 \times 10^{4}(5.8-5.9)$ \\
\hline $\begin{array}{l}\text { H. hauckii- } \\
\text { Richelia } \\
\text { symbioses }\end{array}$ & $58 \|$ & $1.0 \times 10^{4}$ & $\begin{array}{l}8.1 \times 10^{5} \\
(100)\end{array}$ & $1.3 \times 10^{5}$ & $7.5 \times 10^{6}(99.3)$ & $1.9 \times 10^{4}$ & $1.1 \times 10^{6}(86-88)$ \\
\hline \multicolumn{8}{|l|}{ R. clevei- } \\
\hline Symbioses & $58 \|$ & bd & na & $2.9 \times 10^{2}$ & $1.7 \times 10^{4}(0.2)$ & $1.1 \times 10^{3}$ & $6.4 \times 10^{4}(5.0-5.1)$ \\
\hline \multicolumn{8}{|c|}{$\begin{array}{l}\text { Abundance values are the median value of all data points (samples with no detection and detected, not quantifiable were removed); bd, where median } \\
\text { value could not be determined since values ranged below detection to a maxima; na, not applicable because no median value was determined. The values } \\
\text { in parenthesis represent the percentage of total. } \\
\text { Abundances of unicellular Groups A, B, and C were pooled, and a range in } \mathrm{N}_{2} \text { fixation rate was determined considering the range in rates reported or } \\
\text { derived from Montoya et al. (2004) and Reddy et al. (1993). } \\
\text { As reported in Capone et al. (2001). } \\
\text { Is reported in Tuit et al. (2004). }\end{array}$} \\
\hline
\end{tabular}

not observed by microscopy. Therefore, the dominance of one DDA ( $H$. hauckii-Richelia) over the others could be attributable to a lower abundance (Richelia of $R$. clevei) or complete absence (Calothrix of Chaetoceros) of the particular symbiotic strain to associate with the respective host.

The seasonal flow of the Amazon River is NW toward the Caribbean Sea during midwinter to spring (MullerKarger et al. 1988; 1995), which was consistent with the spatial distributions of nifH genes in surface waters. For example, a significant $(p<0.05)$ and positive correlation $\left(r^{2}=52\right)$ was found between salinity and nifH gene copy abundance (liter-1) for surface populations of $H$. hauckiiRichelia along the cruise transect. The highest abundances of the H. hauckii-Richelia symbioses in surface waters were observed at Sta. 7 and $9\left(6-8^{\circ} \mathrm{N}, 51-52^{\circ} \mathrm{W}\right)$. These were also stations with elevated concentrations of silicates and phosphates and where large vegetative cells of Richelia associated with $H$. hauckii were observed by microscopy. Subsequent stations with high abundances and "healthy", Richelia trichomes were noted during April at Sta. 15, 27, 28, and 29 and later in May at Sta. 66 and 67. All of these stations were NW of the Amazon River. Sta. 15, 27, and 28 were also stations where the highest abundances of $H$. hauckii-Richelia symbioses at the surface were observed. The Trichodesmium spp. and unicellular cyanobacteria Group A, B, and C phylotypes had similar patterns of increasing surface concentrations in the NE region of the cruise transect.

There was some evidence for an eastern-flowing tongue of lower surface salinity water. Sta. 31, 33, 35, and 37 were sampled within the meandering lower salinity lens, and generally the unicellular cyanobacteria groups were more abundant along with Trichodesmium and the $R$. cleveiRichelia symbioses. These stations also had lower nifH gene abundances for Richelia associated with $H$. hauckii. Larger trichomes of Richelia associated with $R$. clevei were observed by microscopy at Sta. 33, 35, and 37, and the Richelia associated with $H$. hauckii were composed of only terminal heterocysts (no vegetative cells), which is indicative of cell disintegration (Villareal 1990). The microscopy observations and higher abundances of nifH genes suggest that surface oligotrophic conditions were more favorable for free-living cyanobacteria and the $R$. cleveiRichelia symbioses. Furthermore, degrading H. hauckiiRichelia cells, as evidenced by the microscopy observations, could have been a source of recycled silicates and other nutrients for the co-existing community, i.e., $R$. clevei cells.

The Trichodesmium spp. and unicellular cyanobacteria nifH gene abundances were similar to cell abundances reported previously in the same geographic region (Carpenter and Romans 1991; Falcon et al. 2004; Capone et al. 2005). Falcon et al. (2004) reported $0-5 \times 10^{5}$ cells $\mathrm{L}^{-1}$ for cells $2.5 \mu \mathrm{m}$ in diameter, with a subsurface maximum at 25 m. The unicellular cyanobacterial Groups A, B, and C nifH gene abundances were similar (below detection, $10^{6}$ nifH gene copies $\mathrm{L}^{-1}$ ), but the subsurface maximum abundance was at deeper depths (30-45 m, i.e., Group B Sta. 7, 31, 33, and 37). A similar pattern of near surface maxima in abundance has been observed at station ALOHA (A Longterm Oligotrophic Habitat Assessment) in the subtropical Pacific Ocean for unicellular Groups A and B (Falcon et al. 2004; Church et al. 2005a; 2005b). There are no previous estimates for Group $\mathrm{C}$ abundance before this study, but nifH sequences (Cyanothece-like) were recently reported from a location east of this study area $\left(10^{\circ} \mathrm{N}, 30.3^{\circ} \mathrm{W}\right)$ that were $99 \%$ similar (BLASTN) to our Group C sequence (Langlois et al. 2005).

The highest nifH gene copy estimates for Trichodesmium spp. and the unicellular cyanobacterial groups (Groups A, 
$\mathrm{B}$, and C) were recovered from stations with low surface nutrients and higher salinities and temperatures, and generally in the easternmost regions. These oligotrophic conditions are consistent with the results of laboratory and field studies of Trichodesmium spp. that predict maximal abundances in regions of low wind stress, low concentrations of combined nitrogen, and elevated water temperatures (between $25^{\circ} \mathrm{C}$ and $30^{\circ} \mathrm{C}$ ) (Capone et al. 1997; Laroche and Breitbarth 2005). There is little information on conditions that promote the abundance of the unicellular cyanobacterial types, since only Group B types have been cultivated (related to Crocosphaera watsonii WH8501) and most reports of diazotrophic unicellular cyanobacteria abundances are from the subtropical North Pacific Ocean (Zehr et al. 2001b; Montoya et al. 2004; Church et al. $2005 a$ ). Some studies have provided evidence for temperature limits on the distribution of unicellular cyanobacterial diazotrophs (Mazard et al. 2004; Langlois et al. 2005). However, there are inconsistencies between studies and methods (i.e., PCR for 16S rRNA versus PCR for nifH).

It has been argued that recycled nutrients introduced by the offshore advection of the river plume, eddy upwelling, and anticyclonic features induce the algal blooms observed in the WTNA. Within the low salinity lens, the nifH gene abundances of the diazotrophic targets were detected and the $H$. hauckii-Richelia symbiosis nifH gene abundances were especially high with distance to the NW of the plume. Subsequently, there was evidence for a eastern-moving intermediate salinity lens that was coincident with an increase in Trichodesmium and the free-living nifH phylotype abundances. Therefore, it seemed that there was a diazotrophic cascade from symbiotic to free-living, and likely the activity of these diazotrophs and the release of fixed nitrogen is an equally important factor in bloom formation and maintenance in the WTNA (Carpenter et al. 1999; Hood et al. 2004). The abundance of Richelia associated with $H$. hauckii diatoms was significantly $(p<$ 0.001) different from all other phylotypes, lending further evidence that these diazotrophic populations were in fact distributed differently.

Ultimately a broader understanding of species distribution in the world's oceans is required to make better estimates for global carbon and nitrogen budgets. The QPCR approach provides a relatively fast and efficient means for quantifying diazotrophs in oligotrophic oceanic waters. The next obvious step is linking the abundance of an organism with its contribution to primary and new production. Estimated cell-specific rates of $\mathrm{N}_{2}$ fixation have been proposed for each group and were combined with the QPCR data to estimate the contribution of each phylotype to $\mathrm{N}_{2}$ fixation (Table 5). Since the $H$. hauckii symbioses were in bloom conditions, the hypothetical $\mathrm{N}_{2}$ fixation rates were highest (89-100\% of total) in all salinity regimes. Not intuitively obvious was the contribution by the smaller unicellular groups. In fact, these represented $0.2 \%$ and $1.8 \%$ of the total, respectively, in the intermediate and high salinity environments. Trichodesmium and RhizosoleniaRichelia were $0.3 \%$ and $5.9 \%$, and $0.2 \%$ and $5.0 \%$, respectively. Although, these numbers are significantly less than that of $H$. hauckii-Richelia, it lends further evidence that these other diazotrophic populations, even in the background of a bloom, are an important and understudied new source of nitrogen and, likely, carbon to the co-existing phytoplankton populations in the WTNA.

\section{References}

Berman-Frank, I., J. T. Cullen, Y. Shaked, R. M. Sherrell, AND P. G. Falkowski. 2001. Iron availability, cellular iron quotas, and nitrogen fixation in Trichodesmium. Limnol. Oceanogr. 46: 1249-1260.

Borstad, G. A. 1982a. The influence of the meandering Guiana Current and Amazon River discharge on surface salinity near Barbados. J. Mar. Res. 40: 421-434.

1982b. The influence of the meandering Guiana Current on surface conditions near Barbados-temporal variations of Trichodesmium (Cyanophyta) and other plankton. J. Mar. Res. 40: 435-452.

CAPone, D. G. 2001. Marine nitrogen fixation: what's the fuss? Curr. Opin.Microbiol. 4: 341-348.

, J. P. Zehr, H. W. Paerl, B. Bergman, and E. J. CARPENTER. 1997. Trichodesmium: a globally significant marine cyanobacterium. Science 276: 1221-1229.

— AND OTHERS. 2005. Nitrogen fixation by Trichodesmium spp.: An important source of new nitrogen to the tropical and subtropical North Atlantic Ocean. Global Biogeochem. Cy. 19: GB2024, doi:10.1029/2004GB002331.

Carpenter, E. J., J. P. Montoya, J. Burns, M. Mulholland, A. Subramaniam, and D. G. CAPONE. 1999. Extensive bloom of a $\mathrm{N}_{2}$ fixing symbiotic association in the tropical Atlantic ocean. Mar. Ecol. Prog. Series. 185: 273-283.

, AND K. Romans. 1991. Major role of the cyanobacterium Trichodesmium in nutrient cycling in the North Atlantic Ocean. Science 254: 1356-1358.

- A. Subramaniam, and D. G. Capone. 2004. Biomass and primary productivity of the cyanobacterium Trichodesmium spp. in the tropical N Atlantic ocean. Deep-Sea Res. Pt IOceanog. Res. 51: 173-203.

Church, M. J., B. D. Jenkins, D. M. Karl, and J. P. Zehr. 2005a. Vertical distributions of nitrogen-fixing phylotypes at Station ALOHA in the oligotrophic North Pacific Ocean. Aquat. Microb. Ecol. 38: 3-14.

, - C. Short, D. M. Karl, and J. P. Zehr. $2005 b$. Temporal patterns of nitrogenase (nifH) gene expression in the oligotrophic North Pacific Ocean. Appl. Environ. Microbiol. 71: 5362-5370.

Coale, K. H., K. S. Johnson, S. E. Fitzwater, S. P. G. Blain, T. P. Stanton, and T. L. Coley. 1998. IronEx-I, an in situ iron-enrichment experiment: Experimental design, implementation and results. Deep-Sea Res. Pt Ii-Top St. Oce. 45: 919-945.

Corredor, J. E., AND J. M. Morell. 2001. Seasonal variation of physical and biogeochemical features in the eastern Caribbean surface water. J. Geophys. Res. 106: $4517-4525$.

Del Vecchio, R., and A. Subramaniam. 2004. Influence of the Amazon River on the surface optical properties of the western tropical North Atlantic Ocean. J. Geophys. Res. 109: $1-13$.

Demaster, D. J., G. B. Knapp, and C. A. Nittrouer. 1983. Biological uptake and accumulation of silica on the Amazon continental shelf. Geochimica Cosmochimica Acta. 47: $1713-1723$.

Falcon, L. I., E. J. Carpenter, F. Cipriano, B. Bergman, and D. G. CAPONE. 2004. $\mathrm{N}_{2}$ fixation by unicellular bacterioplankton from the Atlantic and Pacific Oceans: Phylogeny and in situ rates. Appl. Environ. Microbiol. 70: 765-770. 
Falkowski, P. G. 1997. Evolution of the nitrogen cycle and its influence on the biological sequestration of $\mathrm{CO}_{2}$ in the ocean. Nature 387: 272-275.

Foster, R. A., AND J. P. Zehr. 2006. Characterization of diatomcyanobacteria symbioses on the basis of nifH, het $R$ and $16 \mathrm{~S}$ rRNA sequences. Environ. Microbiol. 8: 1913-1925.

Fu, G., K. S. Baith, and C. R. McClain. 1998. SeaDAS: The SeaWIFS data analysis system, p. 73-79. In Proceedings of the 4th Pacific Ocean Remote Sensing Conference. Qingdao, China.

Gómez, F., K. Furuya, and S. Takeda. 2005. Distribution of the cyanobacterium Richelia intracellularis as an epiphyte of the diatom Chaetoceros compressus in the western Pacific Ocean. J. Plankton. Res. 27: 323-330.

Hecky, R. E., and P. Kilham. 1988. Nutrient limitation of phytoplankton in freshwater and marine environments: A review of recent evidence on the effects of enrichment. Limnol. Oceanogr. 33: 796-822.

Hood, R. R., V. J. Coles, and D. G. Capone. 2004. Modeling the distribution of Trichodesmium and nitrogen fixation in the Atlantic Ocean. J. Geophys. Res. C. Oceans 109, C06006, doi:10.1029/2002JC001753.

Janson, S., B. Wouters, B. Bergman, and E. J. Carpenter. 1999. Host specificity in the Richelia-diatom symbioses revealed by $h e t R$ gene sequence analysis. Environ. Microbiol. 1: 431-438.

Karl, D., AND others. 2002. Dinitrogen fixation in the world's oceans. Biogeochemistry 57/58: 47-98.

Kustka, A., E. J. Carpenter, and S. A. SAÑudo-Wilhelmy. 2002. Iron and marine nitrogen fixation: progress and future directions. Res. Microbiol. 153: 255-262.

Langlois, R., J. Laroche, and P. A. RaAb. 2005. Diazotrophic diversity and distribution in the tropical and subtropical Atlantic Ocean. Appl. Environ. Microbiol. 71: 7910-7919.

Laroche, J., And E. Breitbarth. 2005. Importance of the diazotrophs as a source of new nitrogen in the ocean. J. Sea. Res. 53: 67-91.

Longhurst, A. 1993. Seasonal cooling and blooming in tropical oceans. Deep-Sea Res. I 40: 2401-2415.

LuDwiG, W., AND OTHERs. 2004. ARB: A software environment for sequence data. Nucleic Acids Res 32: 1363-1371.

Mazard, S. L., N. J. Fuller, K. M. Orcutt, O. Bridle, and D. J. SCANLAN. 2004. PCR analysis of the distribution of unicellular cyanobacterial diazotrophs in the Arabian Sea. Appl. Environ. Microbiol. 70: 7355-7364.

Montoya, J. P., C. M. Holl, J. P. Zehr, A. Hansen, T. A. Villareal, and D. G. Capone. 2004. High rates of $\mathrm{N}_{2}$ fixation by unicellular diazotrophs in the oligotrophic Pacific Ocean. Nature 430: 1027-1032.

Muller-Karger, F. E., C. R. McClain, and P. L. Richardson. 1988. The dispersal of the Amazon's water. Nature 333: $56-59$.

, P. L. Richardson, and D. McGillicudy. 1995. On the offshore dispersal of the Amazon's plume in the North Atlantic: Comments on the paper by A. Longhurts, "Seasonal cooling and blooming in the tropical oceans." Deep-Sea Res. I 42: $2127-2173$.

O'Reilly, J. E. A. 2000. SeaWiFS postlaunch calibration and validation analyses, p. 1149. NASA.

Perry, G. D., P. B. Duffy, And A. N. L. Miller. 1996. An extended data set of river discharges for validation of general circulation models. J. Geophys. Res. 101: 21339-21349.
Reddy, K. J., J. B. Haskell, D. M. Sherman, and L. A. Sherman. 1993. Unicellular, aerobic nitrogen-fixing cyanobacteria of the genus Cyanothece. J. Bacteriol. 175: 1284-1292.

Ryther, J. H., AND W. M. Dunstan. 1971. Nitrogen, phosphorus, and eutrophication in the coastal marine environment. Science 171: 1008-1013.

Short, S. M., B. D. Jenkins, And J. P. Zehr. 2004. Spatial and temporal distribution of two diazotrophic bacteria in the Chesapeake Bay. Appl. Environ. Microbiol. 70: 2186-2192.

Smith, W. O., And D. J. Demaster. 1996. Phytoplankton biomass and productivity in the Amazon River plume: Correlation with seasonal river discharge. Continent. Shelf. Res. 16: 291-319.

Smith, W. O. J., AND G. J. Russell. 1995. Phytoplankton biomass and nutrient distributions in the Amazon River plume: environmental correlates. Geo-Marine Letters 15: 195-198.

Suzuki, M. T., L. T. TAYlor, and E. F. Delong. 2000 Quantitative analysis of small-subunit rRNA genes in mixed microbial populations via 5 '-nuclease assays. Appl. Environ. Microbiol. 66: 4605-4614.

TAYlOR, F. J. R. 1982. Symbioses in marine microplankton. Ann. Inst. Oceanogr. (Paris) 58: 61-91.

Tuit, C., J. B. Waterbury, and G. Ravizza. 2004. Diel variation of molybdenum and iron in marine diazotrophic cyanobacteria. Limnol. Oceanogr. 49: 978-990.

Tyrrell, T. 1999. The relative influences of nitrogen and phosphorus on oceanic primary production. Nature 400: 525-531.

Van Oppen, M. J. H., F. P. Palstra, A. M. T. Piquet, and D. J. MiLLER. 2001. Patterns of coral-dinoflagellate associations in Acropora: Significance of local availability and physiology of Symbiodinium strains and host-symbiont selectivity. Proc. R. Soc. Lond. Ser. B 268: 1789-1767.

Villareal, T. 1989. Division cycles in the nitrogen-fixing Rhizosolenia (Bacillariophyceae)-Richelia (Nostocaceae) symbiosis. British Phycological Journal 24: 357-365.

1990. Laboratory cultivation and preliminary characterization of the Rhizosolenia (Bacillariophyceae)-Richelia (Cyanophyceae) symbiosis. P.Z.S.N. I: Mar. Ecol. 11: 117-132.

. 1994. Widespread occurrence of the Hemiaulus-cyanobacterial symbiosis in the southwest north-Atlantic Ocean. Bull. Mar. Sci. 54: 1-7.

Waterbury, J. B., and R. Rippka. 1989. Cyanobacteria. Subsection I. Order chroococcales wettstien 1924, Emend. Rippka et al., 1979. In J. T. Staley [ed.], Bergey's manual of systematic bacteriology. V. 3. Williams \& Wilkins.

Woods, J. D. 1988. Mesoscale upwelling and primary production. D. Reidel.

Zehr, J. P., E. J. Carpenter, and T. A. Villareal. 2000. New perspectives on nitrogen-fixing microorganisms in tropical and subtropical oceans. Trends Microbiol. 8: 68-73.

, AND P. J. TURNER. 2001a. Nitrogen fixation: Nitrogenase genes and gene expression. In J. H. Paul [ed.], Methods in marine microbiology. Academic Press.

$\longrightarrow$, AND OTHERS. 2001b. Unicellular cyanobacteria fix $\mathrm{N}_{2}$ in the subtropical North Pacific Ocean. Nature 412: 635-638.

Received: 19 June 2006 Accepted: 13 October 2006 Amended: 28 September 2006 